\title{
Crohn's disease: Symptoms, diagnosis, management by medical and alternative treatment
}

\author{
Rakesh K. Sindhu ${ }^{1 *}$, \\ Annima Goyal ${ }^{1}$, \\ Jaya Das ${ }^{1}$ \\ Neha ${ }^{1}$, \\ Sandeep Arora ${ }^{1}$ \\ ${ }^{1}$ Chitkara College of Pharmacy, Chitkara \\ University, Punjab, India
}

*Corresponding author:

Rakesh K. Sindhu rakesh.sindhu@chitkara.edu.in
Keywords:

Crohn's disease; T-cells;

Inflammation; Immune system; Alternative medicines https://www.pharmacy.mahidol.ac.th/journal/ (c) Faculty of Pharmacy, Mahidol University (Thailand) 2021

\begin{abstract}
Crohn's Disease (CD) insinuates to chronic inflammation of the intestine where the inflammation is greatly T-cell mediated. The perception of $C D$ at present stretch is restricted, public health inspections are carried out as it supports eminent aptitude. It's more common in the developed countries. CD is a recurrent, dynamic and deadly infection. CD is not easy to diagnose due to the overlapping symptoms. It has been elucidated that $\mathrm{CD}$ commonly develops at a young age, usually before the age of 17 . About $20 \%$ of the population suffering from $\mathrm{CD}$ is most commonly linked with family background bearing inflammatory bowel diseases (IBD). This review elucidates the history, epidemiology, etiology, signs and symptoms, pathophysiology, diagnosis and treatment of $\mathrm{CD}$ for better management and to provide appropriate treatment for the disease. No permanent cure of the disease is yet known but the symptoms of the disease can be managed through medication, surgical resection and some alternative medicines for cure of this disease.
\end{abstract}

\section{INTRODUCTION}

Inflammatory bowel diseases occur as the persisting provocative disorder of gastrointestinal tract (GIT) and are categorized by chronic repetitive ulceration of the intestines. IBD roots serious signs in the GIT that are diarrhea, bleeding, abdominal pain, anemia along with weight $\operatorname{loss}^{1}$. IBD is certainly different from irritable bowel syndrome (IBS). IBS is defined as a defect of muscle contraction of the bowel and IBD signifies intestinal inflammation.

IBD has been categorized into 2 categories i.e. $\mathrm{CD}$ and Ulcerative Colitis (UC).

UC is restricted to large intestine (colon and rectum); taking place as (at a) constant configuration; and swelling arising in the deepest layer of intestine.

$\mathrm{CD}$ is a compulsive idiopathic IBD, which chiefly arises in the small intestine as well as in the beginning of large intestine ${ }^{2}$. CD results from $\mathrm{T}$-cell initiated characteristic inflammation caused usually by innocuous commensal bacteria or bacterial products. In $\mathrm{CD}$, the covering of the GIT gets inflamed. Any portion of the tract can be altered, though it generally happens in ileum and colon ${ }^{3}$.

CD also affects the other parts of GIT - the mouth, esophagus and stomach. GIT is a chain of hollow structures/ organs/ body parts in an elongated twisty duct i.e. from mouth to anus. Here, the digestion takes place along with the release of hormones and enzyme.

CD may emerge in bits. It possibly can extend across the entire thickness of bowel wall. CD also affects eyes, skin and joints in some cases. CD leads to ulceration, swelling and wounding of 
the bowels. CD appears very slowly but as the time passes by, it worsens, while even leading to period where symptoms of $\mathrm{CD}$ disappear in patients. This situation can last from a few weeks to many years ${ }^{4}$. $\mathrm{CD}$, which is cogitated to be an ailment of the $20^{\text {th }}$ century, it appears so that there were instances recorded of this since 1769 as granulomatous $\mathrm{IBD}^{5}$.

Maintenance of $\mathrm{CD}$ recurrence post operation is well maintained with early colonoscopy and treatment step-up for recurrence far healthier than conventional drug therapy ${ }^{6}$.

Adequate treatment combined with proper diagnosis prevents the risk of lethal consequence in case of child or adolescent. However, chronic $\mathrm{CD}$ may lead to in lengthy hospitalizations, numerous surgeries, development failure, undernourishment, puberty delay and poor quality of life ${ }^{7}$.

In the recent times, drugs or medicative therapy focus to persuade and conserve the patient in remission and alleviate the disease's auxiliary effects instead of moderating or annulling the fundamental pathogenic mechanism. A recent method for the cure of IBD by means of personified monoclonal antibody formulation has been manufactured. This will boost consequences and might even deliver a comfortable substitute to the conventional cures since these antibody cures can transform the affected biochemical inflammatory pathways. The foremost task has been to dispense the medication to the suitable spot in the GIT, such that the second-generation mediators have been industrialized with enhanced drug delivery, amplified effectiveness and reduced side effects. The ongoing and upcoming researches are more focused on the discovery of drugs that would effectively work on the specific site of inflammation ${ }^{8}$.

The general goals of the treatment for $\mathrm{CD}$ are: a. To attain the finest potential scientific workroom and histologic controller of the provocative disorder with minimum unfavorable effects after treatment.

b. To enable the serene patient to serve as naturally as viable.

c. In children, to stimulate progress with satisfied/ adequate nutrition ${ }^{9}$.

The etiology of IBD is multistep; it may be passed on via heredity or may occur due to environmental interactions ${ }^{10}$.

\section{ETIOLOGY}

What is the predication and life anticipation for Crohn's disease?

Since the precise reason for the occurrence of CD are not yet identified/ discovered. Scientists have found out some primitive factors which may be accountable for triggering $\mathrm{CD}$. These contributing agents/factors are:

Immune system: $\mathrm{CD}$ may sometimes be provoked by virus or bacterium. It is possible that the immune response to fight the invading microorganisms might attack the cells in the digestive tract too, which promotes $\mathrm{CD}$.

Heredity: Genes play a susceptible role in the disease. People having a family history of IBD are likely to acquire CD.

Environmental factors: Environment also contributes to the situation meaning there may be some bacteria, viruses, unidentified factor present that triggers a peculiar response.

The other reasons for CD can also be pinned to the overuse of: - NSAIDS, antibiotics, oral contraceptives and increasingly high content of fat in current diet patterns. Adding to count of the highlighted affecting factors is the habit of smoking $^{3,11}$. The Figure 1 shows the different factors responsible for $\mathrm{CD}$.

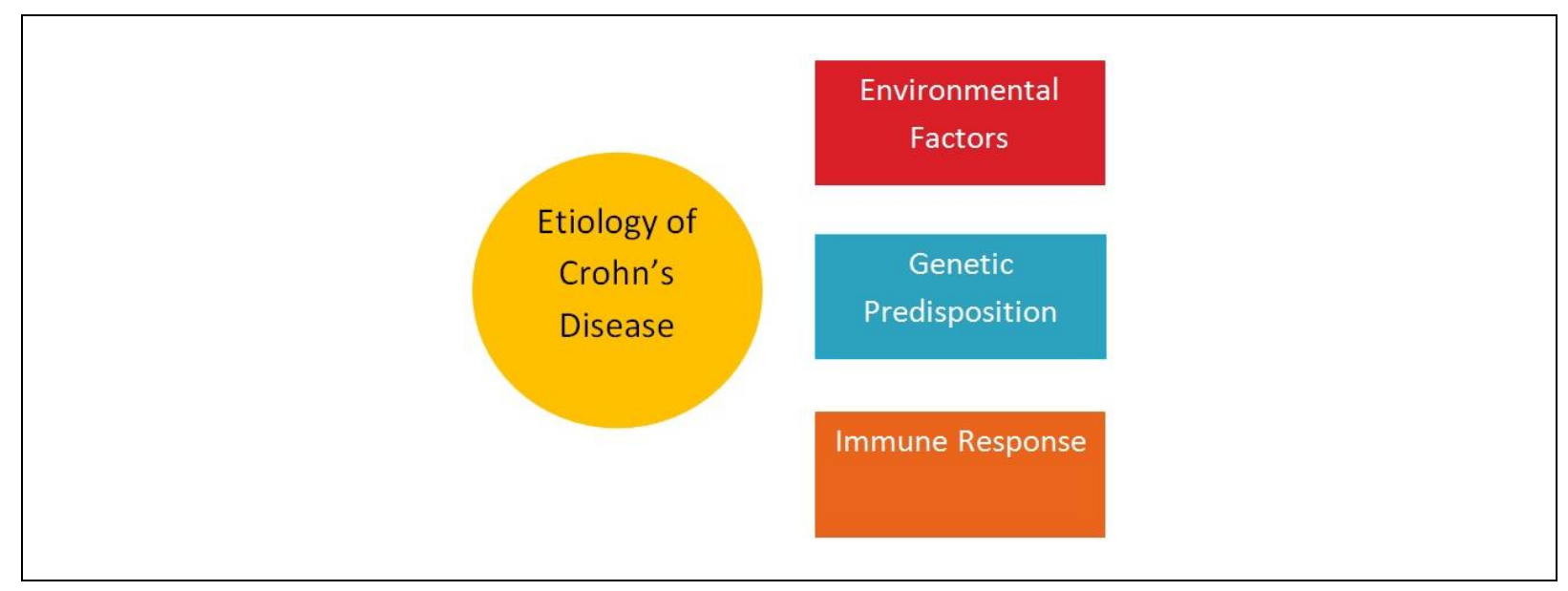

Figure 1. Factors responsible for Crohn's Disease ${ }^{11}$. 


\section{HISTORY OF CROHN'S DISEASE}

Giovanni Battista Morgagni had given the first elucidation of Crohn's; he was the Italian doctor, who identified a patient writhing from a devastating and enduring ailment which triggers diarrhoea. Thereafter more cases got illustrated by John Berg in 1898 and Antoni Lesniowski in 1904 respectively5.

Subsequently, Crohn's transpired to become the foremost Novelist designated as in year 1913 by British Medical Journal, indicating acknowledgements given on the thesis of CD illustrated by him and his associates for the very $1^{\text {st }}$ time. Surprisingly, there arose a conflict to his thesis, when an extremely essential editorial was printed in the same Journal on the same subject by Kennedy Dalziel, a well renowned Doctor practicing at Glasgow, thereon describing the circumstance of the ailment at the British Medical Association Conference. Stating that doctors scanning the patients with the states of disorder had evidently found out swelling in the GIT. Referring to the patients from the era 1920's and 1930's, who had similar symptoms such as diarrhoea, weight loss and abdominal pain ${ }^{4}$.

In 1923, at Mt Sinai Hospital, New York, doctors recognized 12 patients who exhibited these indications. In 1930, Burrill Crohn sighted that the 2 of his patients had the same indications/ complications. On their continuous efforts, in May 1932, a thesis on the circumstances of IBD surfaced in editorial as "Terminal Ileitis," that had been issued in the Journal of American Medical Association (JAMA), which was projected by novelists, Burrill Crohn, Leon Ginzburg, and Gordon D. Oppenheimer. Here they had briefly explained the physiognomies of $\mathrm{CD}$ to the American Medical Association (AMA). The thesis were recognised as an important piece of work, and got published by AMA and in JAMA in the same year and was titled "Regional Ileitis: A Pathologic and Chronic Entity." This incident took place when the doctors were keen/ engrossed in the innovative/ unique inventions/ findings.

$\mathrm{CD}$ was therefore got designated after the renowned gastroenterologist, Burrill Crohn, while initially it was considered as therapeutic condition, as described by him and associates. At the American Medical Association, Burrill Crohn had represented a prototype of his thesis. Evaluation for the past was done for fetching the patients who possibly would have suffered from CD; such patients had been seen in London with disease of small intestine and large intestine, thus stating that $\mathrm{CD}$ had emerged in the earlier $20^{\text {th }}$ century ${ }^{5}$.

\section{EPIDEMIOLOGY}

About, $20 \%$ of the population, suffering from $\mathrm{CD}$, is most commonly linked with family background (history)/ folk bearing IBD. CD affects both men and women equally. It commences more often in individuals who are in 20s and the ones in 50 s to 70 s. Furthermore, the symptoms for CD extend from minor to acute level (degree) ${ }^{6}$.

20\%-30\% Patients are diagnosed with $\mathrm{CD}$, when they inherited the disease, they were younger than 20 yrs. Along with naturally seen GI signs in children with $\mathrm{CD}$, are rectal bleeding and abdominal pain, often experience growth failure, malnutrition, pubertal delay, and bone demineralization ${ }^{7}$.

Children with CD have episodes of severe indications and simultaneously followed by phase of no indications. So the "No Indications" phase is recognized as per "Remission".

The maximum ratio of IBD is high in the most technologically advanced countries, besides the minimum ratio is seen in unindustrialized regions, arctic environment ranges and municipal areas. As per the statistics, CD in North America was 319 per 100,000 people, while in Europe; it was 322 per 100,000 people.

As an example, in Brazil, there has been a yearly escalation of CD since 1990. There is confirmation that $\mathrm{CD}$ is rapidly escalating in Europe and in the recent technologically advanced countries.

On an average, the fistulising or perforating phase is immensities in $17-50 \%$ of the patients with $\mathrm{CD}$ and recurring fistula formation can be seen in about one-third the patients ${ }^{9}$.

\section{PATHOPHYSIOLOGY}

The data recorded for hereditary factors being concerned in pathogenesis of CD arose by the analyses representing higher rates of $\mathrm{CD}$ midst the individuals. The inherent/intrinsic immune system/ organisation is initial primary line of defence alongside contamination ${ }^{10}$.

The complications of $\mathrm{CD}$ are as the below explained.

The pathogenesis of CD includes three contrasting disease progression:

- Inflammatory type: It remains confined to the mucosa and submucosa. Sings include pain and diarrhoea due to partial obstruction. It affects $30 \%$ of the patients. 
- Fistulising or perforating disease: It is prominent in patients with ileitis. It affects $20 \%$ of the patients.

- Transmural inflammation: Intra-abdominal fistulae are produced by aggressive transmural inflammation, that align from diseased bowel wall to another loop, or nearby organ like the urinary bladder.

The immune system physiology of CD arises to be in three brief distinctive categories. Here, STAGE-1 shows the entering of luminal elements into the latent tissues, assisted through ecological aspects viz. septicity, intrinsic faults in mucosal wall. In the healthy people, local macrophages produce provocative cytokines in reaction to matter, causes in neutrophil accretion, vacuuming and then determination. Later in STAGE-2 there is reduced neutrophil incursion due to the impaired discharge of provocative cytokines because of macrophages and followed by cleansing of foreign material. Consequently, STAGE-3 the chronic inflammatory reaction is activated, causing upsurge to distinguishing elements of CD injury. The following Figure 2 describes the 3 stages of $\mathrm{CD}^{11}$.

$\mathrm{CD}$ is a compulsive inflammation due to T-cell activation that causes tissue damage. The type-1 T-helper (Th1) cells along with raised levels of interferon- $\alpha$ and interleukin (IL)-2, play a characteristic role in the defective regulation of $\mathrm{CD}$.

Th- 1 cytokines, specifically IL-12 and tumour necrosis factor (TNF-alpha) influence the inflammatory responses through the release of nonspecific inflammatory substances (such as arachidonic acid metabolites, proteases, platelet activating factor, and free radicals) from the
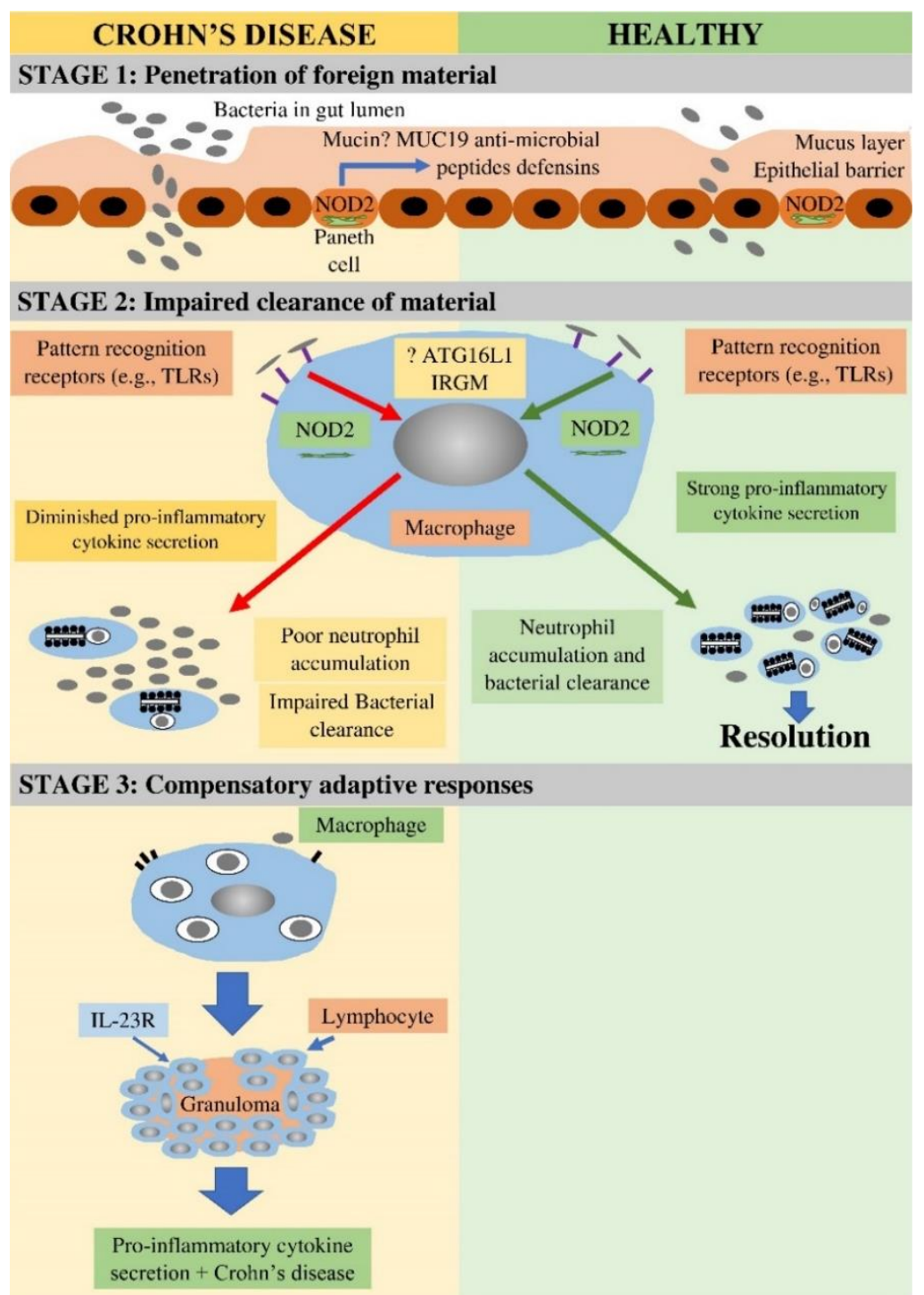

Figure 2. Stages of Crohn's Disease - Immunopathogenesis ${ }^{11}$. 
inflammatory cells forming these cytokines. This leads to a direct injury to the intestine ${ }^{22}$.

A study in 2012 implied that any genetic susceptibility for IBD leads to irregularities in the functioning of the small intestine, particularly in $\mathrm{CD}$, abnormal epithelial barrier integrity and. homeostasis, shortfalls in autophagy, deficiencies in innate pattern recognition receptors. Microscopically, focal inflammatory infiltrates around the crypts initiates the abrasions, subsequently ulceration of the superficial mucosa occurs. Thereafter, the inflammatory cells begin to reach the deeper layers of mucosa and initiates releasing noncaseating granulomas. Later, these granulomas infuse into the layers of the intestinal wall and into mesentery and the regional lymph nodes. Granulomas formation is pathognomonic; however, fistula, benign fibrous strictures and perianal disease are also observed in CD. Thus, the diagnosis is indeterminate. Crypt abscesses leads to the destruction of the crypt and atrophy of the colon. These abscesses are formed by neutrophil infiltration. Chronic damage may result in villous blunting in the small intestine. Ulcerations are often seen upon normal mucosa ${ }^{12}$.

Macroscopically, hyperaemia and oedema of the involved mucosa are initial characteristics. Later, red spots or mucosal depressions are visible due to superficial ulcers and lymphoid aggregations. The mucosa appears like a cobblestone as the red spots become deep, serpiginous ulcers located transversely and longitudinally over an inflamed mucosa ${ }^{13}$.

The bowel wall thickens, and the lumen begins narrowing due to transmural inflammation. Formation of fistulae is observed due to deep ulceration or bowel obstruction aligning the sinus tracts penetrating the serosa, micro perforation, abscess formation, adhesions and mal-absorption. In $\mathrm{CD}$, the fistula travels from the lamina propria muscularis mucosa into deeper layers of the underlying gut wall. Fistula in $\mathrm{CD}$ may be enteroenteral (24\%), enterovaginal (9\%), enterovesical, or enterocutaneous ${ }^{14}$.

Bowel obstruction is intermittent and originates from significant mucosa and associated spasm of the bowel. This can be treated with conservative measures and anti-inflammatory agents. However, chronic obstruction is caused by fibrotic scarring, luminal narrowing, and stricture formation ${ }^{15}$. The mesentery and surrounding lymph nodes may also be involved as the inflammation stretches the bowel wall ${ }^{16}$.

The following chart pictorial Figure 3 will give an easy way to understand the pathophysiology of CD:

\section{SIGNS AND SYMPTOMS}

CD may also affect any section of the digestive tract but predominantly affects the small intestine. CD affects the ileum and the cecum in $40 \%$ cases, the small intestine in $30 \%$ cases and the colon in about $25 \%$ cases.

CD usually affects individual's between the ages of 15 and 40. Signs and symptoms of $\mathrm{CD}$ may range from mild to severe. They develop progressively, however in some cases may occur without warning.

Common signs and symptoms consists of:

- Diarrhoea

- A state of high fever

- Lethargy

- Intestinal ache and contractions/ twinge

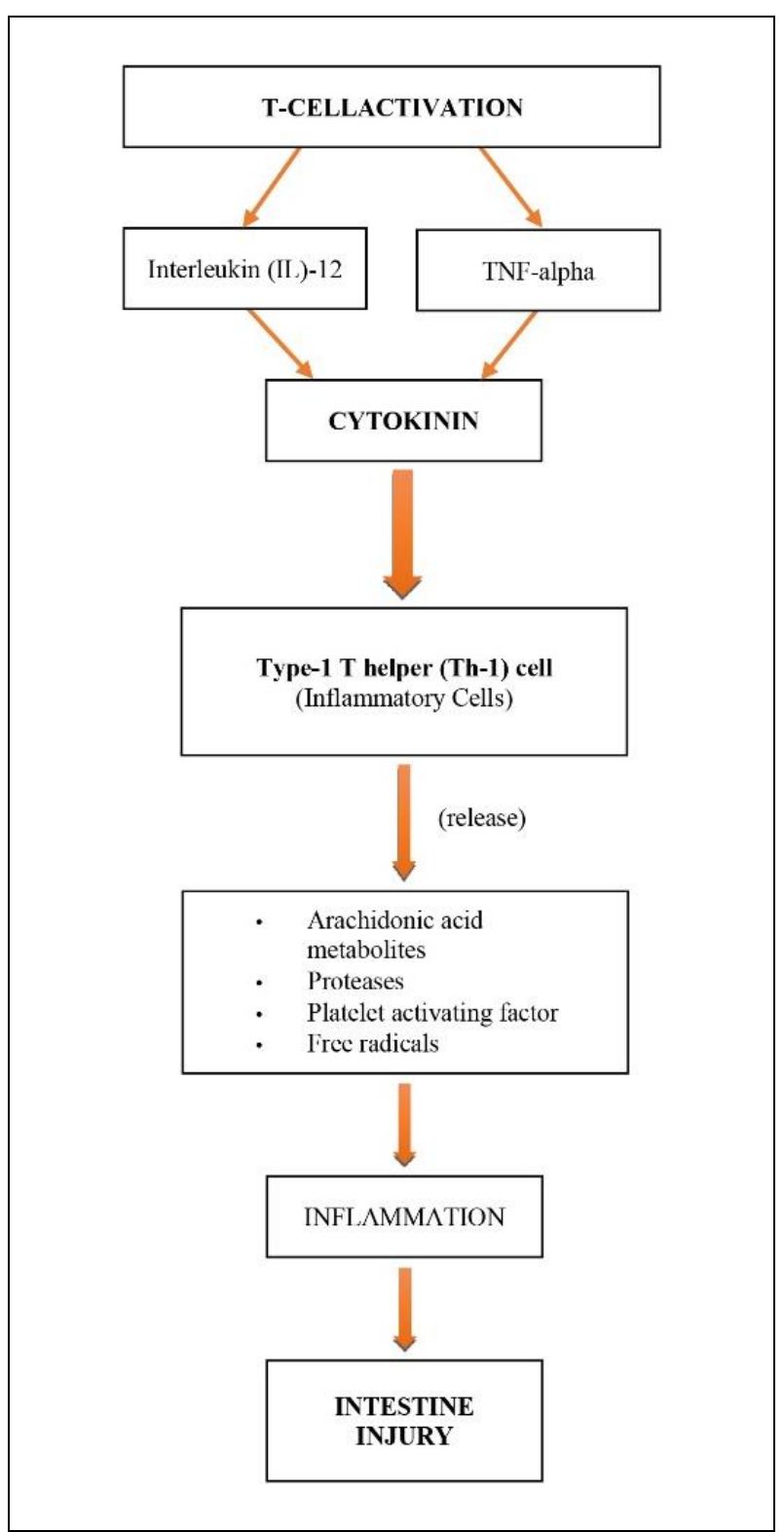

Figure 3. Pathophysiology of Crohn's Disease ${ }^{17}$ 


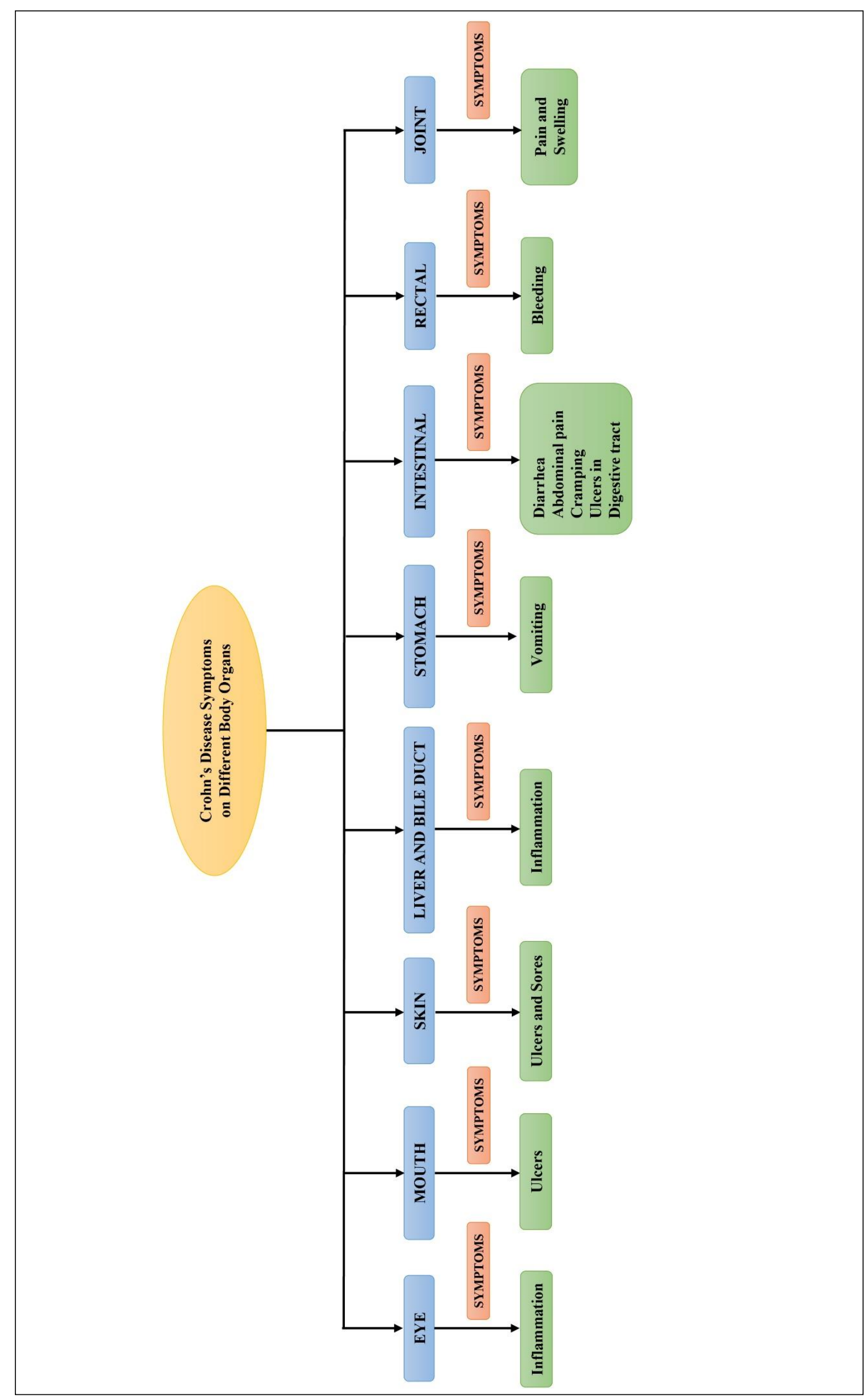

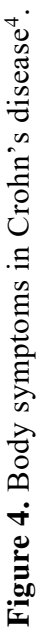


- Blood in faeces

- Mouth irritations

- Abbreviated desire for food and weight loss

- The drainage near or surrounding the anus due to swelling in the skin (fistula)

- Other signs and symptoms

The following may be observed in patients with severe CD:

- Swelling of skin, eyes and joints

- Swelling and infection of the liver or bile ducts

- Deferred growth/maturation or sexual development, in children.

The underneath illustrative Figure 4 Body signs and symptoms in CD:

\section{DIAGNOSIS}

The reoccurrences of CD can be detected on the equipment for radiology and pathological tests $^{18}$.

CD generally affects the young adults. Nearly, $10 \%$ patients develop CD before the age of 17 . There is seen multiplication in the childhood onset IBD. It majorly occurs in males jejunoleitis and require $2^{\text {nd }}$ line immunosuppressants. The childhood onset IBD is completely different from adults suffering from CD.

There are precisely no certain examinations developed for the diagnosis of CD. Test centre checks the blood with the different levels of white blood cells (WBCs), red blood cells (RBCs) or the infections in the digestive tracts.

\subsection{Blood tests}

It is to measure the health-giving red blood cells present in the body as blood loss can lead to anaemia. It will also test the elevated levels of WBCs, which depicts infection in the body. Other tests will check peculiar antibodies. The results obtained from the blood tests will be used by the doctor to diagnose the disease and provide medication accordingly.

\subsection{Stool culture}

In case of any parasite or bacterial infection, stool testing is done.

\subsection{Endoscopy}

It examines the innermost part of the digestive tract, done with a tiny plastic pipe known as endoscope. It consists of a light and a camera lens at the tip. Skin samples can be also taken for examination.

\subsection{Colonoscopy}

It measures the size of large intestine and identifies any kind off unusual outgrowths, swollen tissue, blisters or abscesses and blood loss. This is done by the extensive elastic well-lit tube known as colonoscope.

\subsection{Biopsy}

A section of the skin from the inside layer of the colon and then examined.

Some other techniques for the diagnoses of the disease are:

\subsubsection{Upper GI series or barium swallows}

In this technique the stomach and small intestine are taken. It will examine the allocation, class and seriousness of the disease. In this method barium is consumed orally as it fills the stomach and intestine and is visible as white in X-rays.

\subsubsection{Lower GI series or barium enema}

Here, barium is dispensed through the rectum such that images of the colon and terminal ileum are taken.

\subsubsection{CT enterography or MRI enterography}

Valuation of the small bowel by procedures in which solution with little amount of barium is given to the patient.

\subsubsection{Capsule endoscopy}

A small pill is swallowed by the patient and this contains a camera which films the small intestine. It will capture the inside lining of the intestine and the images are downloaded and viewed on the workstation ${ }^{19}$.

\section{TREATMENT}

For the people suffering from $\mathrm{CD}$ for 10 years almost every patient must have undergone surgery. The patients who have operation have lesser chances of reoccurrence of CD. Inhabitants affected by $\mathrm{CD}$ need orientation and conservation treatment. The orthodox / conservative treatment of IBD require: corticosteroids, immunosuppressants, antibiotics and biologic agents. But the use of such drugs for a lengthier period produces severe side effects.

\subsection{Medicine}

As for now, because there is no kind off 
antidote for $\mathrm{CD}$, the target of the therapy is to:

1) Induce remissions,

2) Maintain remissions,

3) Minimize the side effects of treatment, and

4) Improve the quality of life ${ }^{20}$.

Medicines reduce the inflammation in colon. It will lessen the belly spasms and diarrhoea. Other grave severe situations lead to use of steroids, antibiotics or medicines, which may affect the person's immunity ${ }^{21}$.

\subsection{Diet}

Modifications in the food intake may reduce the symptoms. Fibre is scantily consumed such that it affects the health of patient, so minimal fibre food is suggested. More intake of fluid foodstuff helps in reducing the severe signs. It's eminent for patient to have nourishing and a evaluated balanced diet, as to receive all the essential nutrients.

\subsection{Vitamins}

These will diminish some health difficulties and sustain retardation. This is because the patients do not consume vitamins naturally, thus vitamin scarcity may occur. Some vitamin supplements can also be taken if advised by the doctor.

\subsection{Nutritional supplements}

Nutritional food intake will provide proper nutrition and Total Parenteral Nutrition (TPN) or intravenous nutrition can be used as when the intestine must rest. These are beneficial in case of late growth of the child.

\subsection{Vaccinations}

The adults suffering from $\mathrm{CD}$ may receive single dose of Tdap, next Td boosters in each 10 years $^{23}$. Tdap signifies tetanus (T), diphtheria (D) and pertussis $(\mathrm{P})$. Teenagers $(10,11$ years old $)$ must be administered with single dosage of Tdap $^{24}$. Also, Crohn's MAP (Mycobacterium avium subspecies paratuberculosis) vaccination trials have been carried out by Oxford university and it's assumed as a great development to combat for healing/treating $\mathrm{CD}^{25}$.

\subsection{Surgery}

It will help in shrinking $\mathrm{CD}$ but will not heal it. Surgery can mend certain enigma and deal with prolonged period signs along with medicine ${ }^{26}$.

Different types of surgeries:

\subsubsection{Draining abscesses in or near fistulas}

A pool of infectious discharge i.e. an abscess, cured by antibiotics.

\subsubsection{Bowel or intestinal resection}

The contaminated part of intestine is eradicated. The healthful parts of intestine are joined back but it reduces the length of intestine.

\subsubsection{Ostomy}

This is when a portion of the intestine has been eradicated, and then a different mode is designed for eliminating stool from body. Therefore, this operation to form a different opening is known as ostomy.

The symptoms of CD can be regulated for certain duration by surgical resection but it is more likely to recur ${ }^{27}$.

At the present juncture, a wide range of methodologies are exercised as an attempt and distinguish scientifically and medically open, abnormal hollow strictures from the once which oblige for surgery, for instance imaging (CTE, $\mathrm{MRE}$ ), research laboratory biomarkers (C-reactive protein, erythrocyte sedimentation rate), along with faecal biomarkers (fecal cal-protein). Medical treatment initially averts surgery in a scientifically eloquent fraction of patients ${ }^{28}$. A hypothetical illustration of an oedematous bowel beforehand and afterward the medical treatment is depicted in below Figure 5 .

\subsection{Synthetic and Semi-synthetic medicine}

\subsubsection{Anti-inflammatory agents}

These agents are to reduce the intestinal inflammation analogous to the arthritis agents which reduce the joint inflammation. Some of the different agents consumed to cure $\mathrm{CD}$ are:

- 5-aminosalicylic acid (5-ASA) combinations or mesalamine- Mesalamine is analogous to aspirin. So, 5-ASA is an effectual measure to treat CD. 5ASA activates the peroxisome proliferation-activated receptor gamma (PPAR- $\gamma$ ) which further decreases the activity of NF- $\mathrm{KB}$ including decrease in cytokine production. Consequently, patients are generally supposed to take 5-ASA through oral route in an improvised manner (i.e. alteration are done chemically) and avoids assimilation in the stomach and upper intestine. Some agents - Sulfasalazine [Azulfidine], Mesalamine [Pentasa, Asacol, Dipentum, Colazal, 


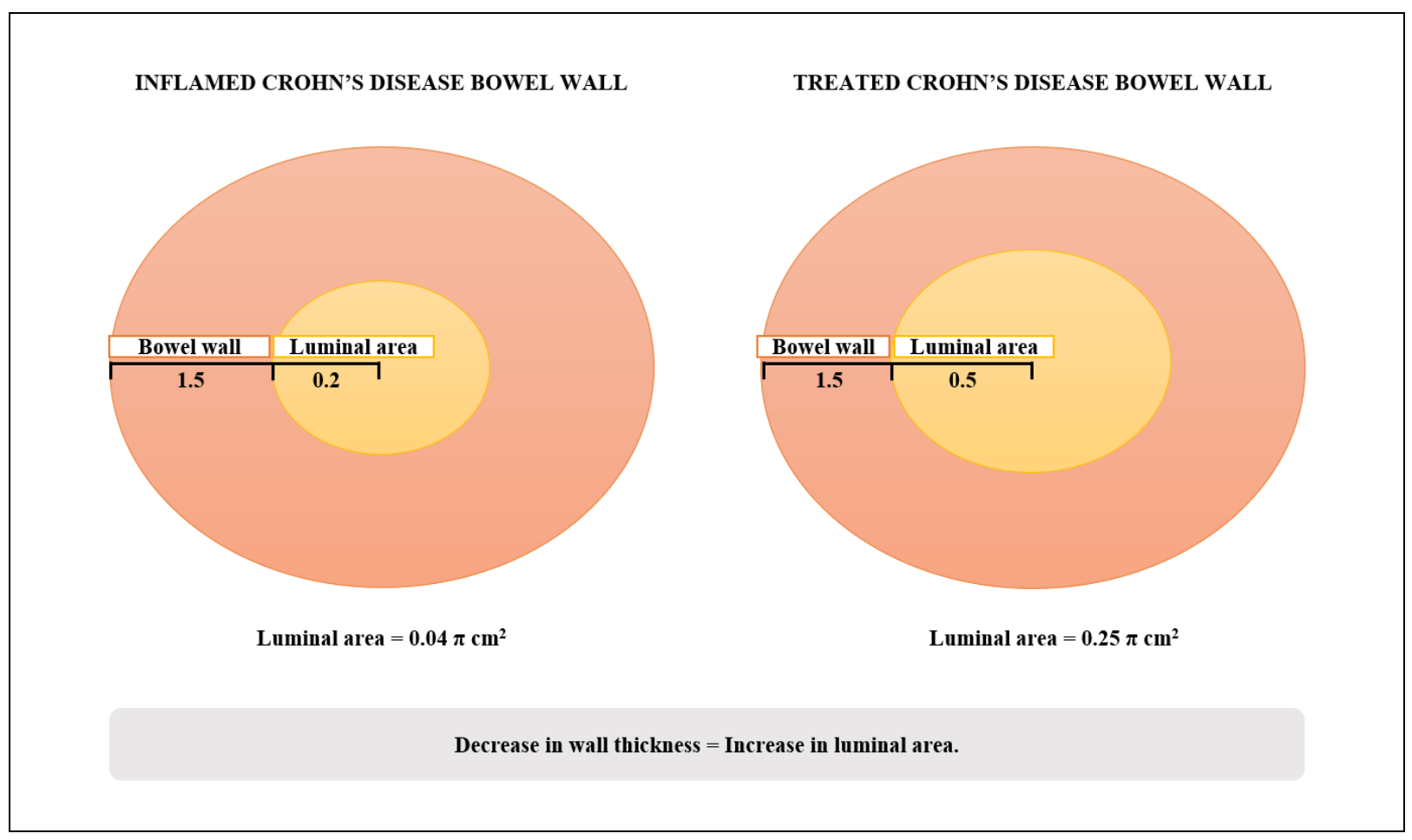

Figure 5. Wall thickness comparison in patient before and after surgery ${ }^{12}$.

Rowasa Enema, Canasa Suppository $]^{29}$.

- Corticosteroids - for curing CD these have been used for ages. In cases, 5-ASA is not effective in curing $\mathrm{CD}$, and then corticosteroids are subscribed. Corticosteroids do not directly come in contact with the inflamed intestinal tissues to be effective. These on being absorbed, exhibit speedy anti-inflammatory action all over the body involving the intestines. In vital patients, corticosteroids are administered intravenously. On topical administration, a fewer amount of corticosteroid is absorbed and acute effects of the drug is declined. These are more rapidly functioning than 5-ASA. Some corticosteroids are: budesonide (Entocort EC), prednisone, prednisolone, hydrocortisone etc ${ }^{30}$.

\subsubsection{Antibiotics}

Metronidazole (Flagyl) and Ciprofloxacin (Cipro) are used for curing CD. Flagyl treats various inflammations caused by parasite and bacterial. It helps in treating anal fistulae. Cipro is consumed in mixture along with metronidazole ${ }^{23,31}$.

\subsubsection{Immune-modulator medication}

These agents reduce the swelling, infection of tissue by diminishing the immunity cells release at the site and by restricting the proteins release. Immune-modulator medicative agents are:

I. 6-Mercaptopurine (6-MP)

II. Azathioprine (Imuran)
III. Methotrexate (Rheumatrex, trexall)

$I V$. Infliximab (Remicade)

$V$. Adalimumab (Humira)

VI. Certolizumab (Cimzia)

VII. Natalizumab (Tysabri) ${ }^{32}$.

\section{Azathioprine (AZA) and 6-mercaptopurine (6-MP)}

Azathioprine and 6-mercaptopurine has been the two common drugs used for the treatment of IBD in the recent years. They are widely used for their immunosuppressive and lymphocytotoxic properties. They are generally thioguanine derivative, wherein, AZA is a prodrug of $6-\mathrm{MP}^{33}$. Treatment with 6-MP has been proven to reduce the use of corticosteroids in approximately $75 \%$ of the patients displaying a media response ${ }^{34}$.

Both AZA and 6-MP act by inhibiting the $\mathrm{T}$ and $\mathrm{B}$ - lymphocytes, thereby decreasing the count of cytotoxic T-cells and plasma cells. The number of lamina propria plasma cells also decreases affecting natural killer cell function by altering the lymphocyte function. Thus, lymphoma and leukaemia can also be treated.

\section{Pharmacokinetics}

6-MP is the by-product of AZA metabolized by enzyme glutathione-S-transferase and then by any of the three enzymes in the liver and gut:

a. Thiopurine-S-methyltransferase (TPMT): converts 6-MP to 6-methyl-MP by catalysing methylation of 6-MP; 
b. Xanthine oxidase: catalyses conversion of 6-MP to thiourate; and

c. Hypoxanthine - guanine - phosphoribosyl transferase: helps to convert 6-MP to 6-thioguanine nucleotides.

In healthy individuals, AZA is absorbed at a rate of $16 \pm 50 \%$ whereas the rate is less in IBD patients as per the aggravations ${ }^{35}$. The bioavailability of 6-MP ranges from 5-30\%.

Dose

AZA dose should be gradually increased within two weeks followed by weekly blood monitoring $(0.5 \pm 1.5 \mathrm{mg} / \mathrm{kg}$ daily to $2.5 \mathrm{mg} / \mathrm{kg})$. 6 -MP dose increases from $0.25 \pm 0.5 \mathrm{mg} / \mathrm{kg}$ to $1.0 \pm 1.5 \mathrm{mg} / \mathrm{kg}$ day-to-day. The drugs are discontinued in case the WBC count and platelet count decreases and liver biochemistry (and/or serum amylase) is more than $50 \%$ of the upper limit until the conditions normalise ${ }^{36}$.

Side Effects ${ }^{37}$

- Allergic reactions

- Neoplasia

- Superinfections

- Hepatitis

- Bone marrow suppression

- Pancreatitis

\section{Methotrexate (MTX)}

MTX is a folic acid analogue that acts as an anti-metabolite. MTX finds a valuable use in the treatment of tumour and cancer, especially acute childhood leukaemia for its ability to inhibit dihydrofolate reductase (DHFR) enzyme.

In CD, MTX finds a third-line treatment in case AZA treatment fails or causes toxicity. MTX is competitively efficient as AZA both in the induction and maintenance of remission ${ }^{38}$. MTX when combined with infliximab, proves to be effective in the induction and maintenance of remission in fistulising $\mathrm{CD}$.

MTX as well shows its action by inhibiting the $\mathrm{T}$-cell responses which in turn alters cytokine production:

a. Enhance secretion of anti-inflammatory cytokines, e.g., IL-10

b. Inhibit proliferative and proinflammatory cytokines.

However, efficacy of MTX in the treatment of CD is because of its ability to inhibit TNF- $\alpha$ via various pathways ${ }^{39}$.

\section{Pharmacokinetics}

MTX is rapidly and completely absorbed via oral and intramuscular administration ${ }^{40}$. However, subcutaneous route is more preferable for the treatment of $\mathrm{CD}^{41}$. The plasma $\mathrm{t}_{\mathrm{t} / 2}$ of
MTX varies from 6-69 hours. It is not highly bound to plasma protein $(\sim 50 \%)$. MTX is excreted majorly via renal excretion, whereas negligible traces are found in other secretions such as, milk and saliva.

MTX is metabolised into various metabolites by intestinal bacteria during absorption, the major of which is 4-amino-4-deoxy-N10-methylpteroic acid. However, only poly- $\gamma$-glutamates metabolite is more efficacious in inhibiting DHFR than MTX itself.

\section{Dose}

A single weekly dose of $20-25 \mathrm{mg}$ subcutaneously is usually effective in the treatment of CD. However, $15 \mathrm{mg}$ dose on a weekly basis is efficacious in maintenance of remission ${ }^{42}$.

\section{Side Effects}

Renal function disorders, myelosuppression, rash, and opportunistic infections, liver enzyme elevations and liver fibrosis are the side effects generally observed at low doses of MTX treatment. The extent of toxicity depends upon the duration of exposure and the dose of plasma concentration. MTX is contraindicated in pregnancy.

Folate supplementation ( 1 to $5 \mathrm{mg} /$ day) along with MTX can reduce toxicity ${ }^{43}$.

\section{TNF- $\alpha$ INHIBITORS}

TNF- $\alpha$ is a cytokine that plays a fundamental role in the pathogenesis of $\mathrm{CD}$. CD can be diagnosed by knowing the level of TNF- $\alpha$ in stool and mucous.

TNF- $\alpha$ therapy is mandatory in the treatment of CD. IgG1 monoclonal antibodies, infliximab, adalimumab, golimumab, vedolizumab, natalizumab and certolizumab bind to TNF and show antagonist effect ${ }^{44}$.

\section{a. INFLIXIMAB}

Infliximab, a nitroimidazole antibiotic was found effective in the induction and maintenance of moderate to severely active $\mathrm{CD}^{45}$. Infliximab is found to prevent the recurrence of CD postsurgery particularly in the nonterminal ileum ${ }^{46}$. Studies revealed that infliximab is effective in the induction therapy and maintenance therapy, in cases of both predominantly or wholly nonfistulizing $C D$ and fistulizing disease ${ }^{47}$. Infliximab is still under trial to determine its efficacy for postoperative CD prophylaxis ${ }^{48}$.

The patient may develop human anti chimeric antibodies (HACAs, also known as antibodies to infliximab) against the drug which causes loss of efficacy, infusion reactions and delayed hypersensitivity reactions ${ }^{49}$. 


\section{Pharmacology}

TNF maintains the inflammatory and immune responses. Thus, all the TNFalpha inhibitors (infliximab, adalimumab and certolizumab) act by inhibiting the interaction of TNF with TNF-receptor in turn providing immune response. Infliximab binds to soluble and transmembrane forms of TNF-alpha and blocks their activity ${ }^{50}$.

\section{Dose $e^{51}$}

For children-(6-17 years): $5 \mathrm{mg} / \mathrm{kg}$ IV at 0,2 , and 6 weeks; q8Weeks thereafter

For adults: $5 \mathrm{mg} / \mathrm{kg}$ IV at 0,2 , and 6 weeks; q8Weeks thereafter

Side effects ${ }^{52}$

- Headache, skin rash, abdominal pain, nausea, diarrhoea

- Increased serum ALT

- Increased antibody development

- Upper respiratory tract infections, sinusitis, cough, pharyngitis

\section{b. ADALIMUMAB}

Adalimumab is an immunoglobulin G1 (IgG1) monoclonal antibody, intended only for human, which attach to TNF-alpha with specificity ${ }^{53}$. Adalimumab was found to be more efficacious than infliximab in the maintenance and induction of disease. This is due to the potential of both the TNF inhibitors to induce cell apoptosis. People treated with adalimumab are observed to develop fewer amounts of antibodies against the drug as compared to infliximab ${ }^{54}$.

\section{Dose}

Initially, $160 \mathrm{mg}$ adalimumab is administered subcutaneously, followed by $80 \mathrm{mg}$ subcutaneously 2 weeks later. $40 \mathrm{mg}$ subcutaneously is continued 2 weeks later ${ }^{55}$.

Side effects ${ }^{56}$

- Serious infections, including tuberculosis and malignancy

- Congestive heart failure, lupus-like syndrome, and demyelinating disorders

\subsection{Alternative treatment}

The harmonizing/ alternative treatment refers to analysis and curative approaches which surely exist outdoor medical complex where traditional remedy is performed. Natural commodities which are acquired from the plants and herbals are progressively used for IBD. These natural products come with minute side effects ${ }^{32}$.

Some of the raw commodities from plants used for the treatment of CD are arranged in a tabular form as below in Table $1^{57-82}$.

Herbal treatment is a successful method to treat $\mathrm{CD}$ without any chain reaction. Mastic gum used for treatment of $\mathrm{CD}$ is effective and safe to use, it did not have any serious noxiousness ${ }^{79}$.

In CD therapy, Tripterygium wilfordii and Artemisia absinthium both were superior to placebo group in induction of remission, as well as in clinical reference and prevention of postoperative $\mathrm{CD}^{80}$. Herbal remedies have no strong evidence as a single effective treatment ${ }^{81}$. The most IBD patients have good response to conventional therapy ${ }^{82}$.

\subsubsection{Precise Mechanism of Herbal Plants:}

\section{a. Anti-inflammatory and Anti-oxidant}

The curatives as anthocyanin enhanced Bilberry extracts, Ginseng extract, Ginkgo biloba extract, Curcuma longa extract and along with blueberry extract, repress the extraction of inflammatory action ${ }^{83}$. Nutritional foodstuffs as pomegranate, Tragopogon graminifolius and blueberry extract work via improvement of its anti-oxidant action, hinderance of DNA oxidative injury and free-radicle foraging also the fatty acid peroxidation ${ }^{84}$.

\section{b. Immune-modulation and NOS modulation}

The death of T-cells signify a crucial procedure of nutritional elements for lightening immune surge alongside mitochondrial arbitrated and fatality-receptor facilitated conduits. The herbal foodstuffs suppress COX action that controls the death of triggered provocative units. More herbal essentials as flavonoids and polyphenols depicts the rise in endothelial NOS manifestation as well as slow down of iNOSelucidation and decrease in iNOS with $\mathrm{NO}^{85-86}$.

\section{c. Cellular Signaling Conduit Modulation}

Numerous natural commodities ought to hold healing/curative ability through modifying triggered protein-kinase followed by reduction of prolonged swelling. Whereas the other herbal commodities, assist in curing of IBD by their action on essential routes of swelling and irritation. As for, curcumin, ellagic acid, flavonoids and polyphenols modify the phosphorylation and neutralize I $\kappa$ B enzyme ${ }^{87}$.

\section{d. Modifications of Gut Microbiota}

The use of herbal medicines may regulate the composition of the gut microbiota and its 
secretions in ulcerative colitis. Consumption of natural product as blueberry causes a chief remission of some major bacteria present in the bowels, even helps in rise of butyric acid in hereditary trial prototype ${ }^{88}$. Mechanism of action of some selected medicinal plants shown in Figure 6.

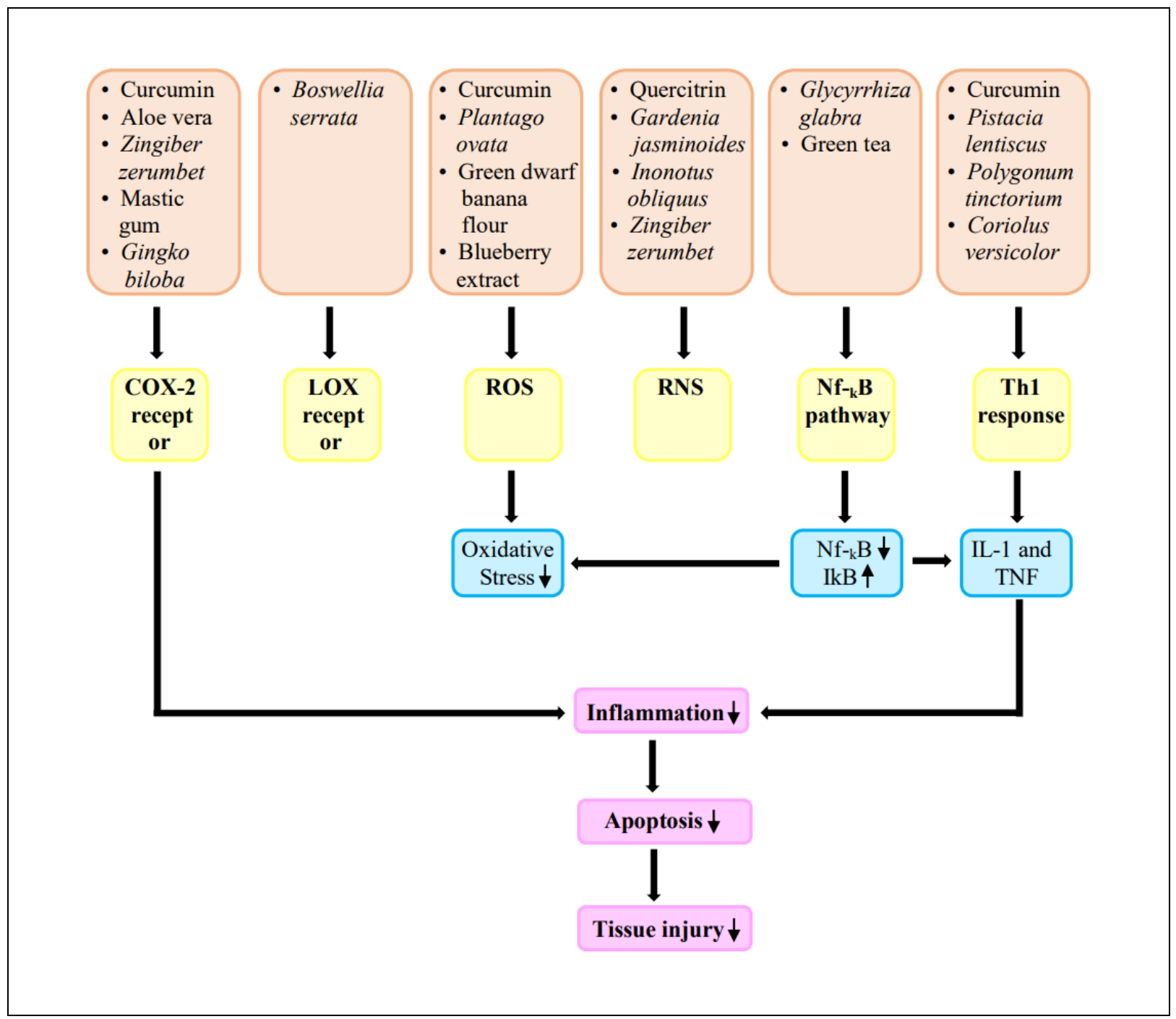

Figure 6. Mechanism of action of Herbal Plants ${ }^{80}$.

Table 1. Plants used in treatment of Crohn's Disease.

\begin{tabular}{|c|c|c|c|c|c|c|}
\hline $\begin{array}{l}\text { Sr. } \\
\text { no. }\end{array}$ & Botanical name & Part of plant & $\begin{array}{l}\text { Extract / } \\
\text { constituents }\end{array}$ & MOA & Use & Ref. \\
\hline 1. & $\begin{array}{l}\text { Pistacia } \\
\text { lentiscus } \mathrm{L} . \\
\text { Family - } \\
\text { Anacardiaceae }\end{array}$ & $\begin{array}{l}\text { Gum/ resin } \\
\text { from shrub }\end{array}$ & $\begin{array}{l}\text { Chios mastic gum. } \\
\text { The major } \\
\text { constituent is } \\
\text { oleanolic acid. }\end{array}$ & $\begin{array}{l}\text { Immunomodulator for } \\
\text { peripheral blood } \\
\text { mononuclear cells } \\
\text { Acts as TNF - alpha } \\
\text { inhibitor. } \\
\text { Also, as a migration } \\
\text { inhibitory factor } \\
\text { stimulator as the } \\
\text { chemotaxis of } \\
\text { monocytes is inhibited. }\end{array}$ & $\begin{array}{l}\text { Antibacterial } \\
\text { Antioxidant } \\
\text { Anti-inflammatory } \\
\text { Healing properties } \\
\text { in intestine, } \\
\text { stomach and liver } \\
\text { Anti-tumor }\end{array}$ & 57 \\
\hline 2. & $\begin{array}{l}\text { Artemisia } \\
\text { absinthium L. }\end{array}$ & Herbs & $\begin{array}{l}\text { Active components } \\
\text {-essential oils, } \\
\text { anabsinthin, }\end{array}$ & $\begin{array}{l}\text { Almost complete } \\
\text { clinical remission in } \\
65 \% \text { patients as }\end{array}$ & $\begin{array}{l}\text { Anti-inflammatory, } \\
\text { antipyretic, and } \\
\text { chemotherapeutic }\end{array}$ & 58 \\
\hline
\end{tabular}


Table 1. Plants used in treatment of Crohn's Disease. (cont.)

\begin{tabular}{|c|c|c|c|c|c|c|}
\hline $\begin{array}{l}\text { Sr. } \\
\text { no. }\end{array}$ & Botanical name & Part of plant & $\begin{array}{l}\text { Extract / } \\
\text { constituents }\end{array}$ & MOA & Use & Ref. \\
\hline & $\begin{array}{l}\text { Family - } \\
\text { Asteraceae }\end{array}$ & & $\begin{array}{l}\text { absinthin, resins, } \\
\text { and organic acids. } \\
\text { The sour taste is } \\
\text { caused by the } \\
\text { glucosides - } \\
\text { absinthin and } \\
\text { anabsinthin }\end{array}$ & $\begin{array}{l}\text { compared to none in } \\
\text { the placebo group } \\
\text { was also noticed that } \\
\text { wormwood had a } \\
\text { steroid sparing effect } \\
\text { and a positive effect on } \\
\text { the quality of life of } \\
\text { patients. }\end{array}$ & $\begin{array}{l}\text { activity } \\
\text { Treat loss of } \\
\text { appetite, dyspepsia, } \\
\text { and biliary } \\
\text { dyskinesia } \\
\text { Used as a } \\
\text { flavouring agent }\end{array}$ & \\
\hline 3. & $\begin{array}{l}\text { Cannabis sativa L. } \\
\text { Family - } \\
\text { Cannabaceae }\end{array}$ & Whole plant & $\begin{array}{l}\text { The main } \\
\text { psychoactive } \\
\text { constituent of } \\
\text { Cannabis is } \\
\text { tetrahydrocannabin } \\
\text { ol and has } 60 \\
\text { cannabinoids. }\end{array}$ & $\begin{array}{l}\text { Marijuana plant } \\
\text { Cannabis amends } \\
\text { inflammatory processes } \\
\text { It inhibits colonic } \\
\text { inflammation, showing } \\
\text { Cannabis may have a } \\
\text { therapeutic role in IBD. } \\
\text { Rate of the use of } \\
\text { Cannabis was noted } \\
\text { before and after the } \\
\text { surgery, there was a } \\
\text { decrease in the usage of } \\
\text { the other drug after } \\
\text { surgery. }\end{array}$ & $\begin{array}{l}\text { Chemotherapy- } \\
\text { induced nausea, } \\
\text { spasticity in } \\
\text { multiple sclerosis } \\
\text { (MS), } \\
\text { treatment-resistant } \\
\text { seizures } \\
\text { Neuropathic pain }\end{array}$ & $\begin{array}{l}59, \\
60\end{array}$ \\
\hline 4. & $\begin{array}{l}\text { Boswellia serrata } \\
\text { Family - } \\
\text { Burseraceae }\end{array}$ & $\begin{array}{l}\text { Gum/ resin } \\
\text { collected from } \\
\text { its stem. }\end{array}$ & $\begin{array}{l}\text { Extracts from the } \\
\text { gum resin } \\
\text { contains oils, } \\
\text { terpenoids, sugars, } \\
\text { and volatile oils. } \\
\text { Four pentacyclic } \\
\text { triterpenes present: } \\
\text { beta-boswellic } \\
\text { acid, acetyl-beta- } \\
\text { boswellic acid, 11- } \\
\text { keto-beta- } \\
\text { boswellic acid, and } \\
\text { acetyl-11-keto- } \\
\text { beta-boswellic acid }\end{array}$ & $\begin{array}{l}\text { Suppress leukotriene } \\
\text { formation as by } \\
\text { inhibition of } 5- \\
\text { lipoxygenase by two } \\
\text { boswellic acids, } 11- \\
\text { keto- } \beta \text { - boswellic acid } \\
\text { and acetyl-11-keto- } \beta \text { - } \\
\text { boswellic acid. }\end{array}$ & $\begin{array}{l}\text { Anti-inflammatory } \\
\text { effects for- asthma, } \\
\text { osteoarthritis, } \\
\text { rheumatoid } \\
\text { arthritis, colitis, and } \\
\text { irritable bowel } \\
\text { syndrome. } \\
\text { Management of } \\
\text { diabetes, urinary } \\
\text { conditions, } \\
\text { dermatological } \\
\text { ailments, and renal } \\
\text { impairment. } \\
\text { Immunomodulator, } \\
\text { antiproliferative, } \\
\text { cytotoxic, and } \\
\text { antimicrobial } \\
\text { effects; } \\
\text { reduces edema. }\end{array}$ & 61 \\
\hline 5. & 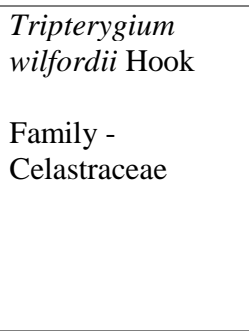 & $\begin{array}{l}\text { Refined extract } \\
\text { of } T \text {. wilfordii }\end{array}$ & $\begin{array}{l}\text { The main } \\
\text { constituent - } \\
\text { diterpenoid } \\
\text { triptolide. } \\
\text { Others - triptolide, } \\
\text { include } \\
\text { sesquiterpenes, } \\
\text { diterpenes and } \\
\text { triterpenes. }\end{array}$ & $\begin{array}{l}\text { Clinical Disease } \\
\text { Activity Index (CDAI) } \\
\text { was radially reduced. } \\
\text { Endoscopic improvement } \\
\text { were seen. } \\
\text { Inflammatory indices } \\
\text { including CRP were } \\
\text { also decreased. }\end{array}$ & $\begin{array}{l}\text { Rheumatoid } \\
\text { arthritis (RA) } \\
\text { Ankylosing } \\
\text { spondylitis } \\
\text { Antifertility } \\
\text { properties in men, } \\
\text { as amenorrhea } \\
\text { perceived in women. }\end{array}$ & 62 \\
\hline 6. & $\begin{array}{l}\text { Curcuma longa } \\
\text { Family - } \\
\text { Zingiberaceae }\end{array}$ & $\begin{array}{l}\text { Roots and } \\
\text { rhizome part is } \\
\text { used. }\end{array}$ & $\begin{array}{l}\text { The active } \\
\text { constituents - } \\
\text { curcuminoids and } \\
\text { diferuloylmethane. }\end{array}$ & $\begin{array}{l}\text { Blocker of TNF-s, } \\
\text { colonic nitrates are } \\
\text { reduced and also } \\
\text { decreases the cyclo- } \\
\text { oxygenase-2 (COX-2). } \\
\text { Reduced loss of body } \\
\text { weight and activity } \\
\text { index is decrease lessens. } \\
\text { It diminishes the } \\
\text { oxidative stress and } \\
\text { hinders the passage of } \\
\text { neutrophils. }\end{array}$ & $\begin{array}{l}\text { Therapeutic } \\
\text { property } \\
\text { Safe to use and } \\
\text { active drug. } \\
\text { Anti-inflammatory } \\
\text { Anti-oxidant } \\
\text { Cancer preventive } \\
\text { property } \\
\text { Treat diabetes } \\
\text { mellitus }\end{array}$ & 63 \\
\hline
\end{tabular}


Table 1. Plants used in treatment of Crohn's Disease. (cont.)

\begin{tabular}{|c|c|c|c|c|c|c|}
\hline $\begin{array}{l}\text { Sr. } \\
\text { no. }\end{array}$ & Botanical name & Part of plant & $\begin{array}{l}\text { Extract / } \\
\text { constituents }\end{array}$ & MOA & Use & Ref. \\
\hline 7. & $\begin{array}{l}\text { Gardenia } \\
\text { jasminoides } \\
\text { Family - } \\
\text { Rubiaceae }\end{array}$ & $\begin{array}{l}\text { Fruits - } \\
\text { Glycoprotein }\end{array}$ & $\begin{array}{l}\text { Ethanol and water } \\
\text { extracts from } \\
\text { gardenia } \\
\text { jasminoides. }\end{array}$ & $\begin{array}{l}\text { Reduced nitric oxide } \\
\text { and diminishes nitric } \\
\text { oxide synthase that in } \\
\text { turn decreases COX } \\
\text { and hence the nuclear } \\
\text { factor kappa-light- } \\
\text { chain-enhancer of } \\
\text { activated b cells is } \\
\text { decreased. }\end{array}$ & $\begin{array}{l}\text { Commonly used } \\
\text { Chinese medicine. } \\
\text { Improves quality of } \\
\text { sleep. } \\
\text { Anti-oxidant } \\
\text { Anti-inflammatory } \\
\text { Anti-diabetic } \\
\text { Anti-depression }\end{array}$ & 64 \\
\hline 8. & $\begin{array}{l}\text { Camellia sinensis } \\
\text { Family - } \\
\text { Theaceae }\end{array}$ & Shrubs & $\begin{array}{l}\text { Theaflavin- } 3,3 \times- \\
\text { digallate and } \\
\text { thearubigin }\end{array}$ & $\begin{array}{l}\text { Reduces nuclear factor } \\
\text { kappa-light-chain- } \\
\text { enhancer of activated b } \\
\text { cells that leads to } \\
\text { decrease in TNF-alpha } \\
\text { and interleukins and } \\
\text { decreased nitric oxide } \\
\text { synthase. }\end{array}$ & $\begin{array}{l}\text { Anti-oxidant } \\
\text { Cholesterol } \\
\text { lowering properties } \\
\text { Neuroprotection } \\
\text { Reduce stress and } \\
\text { anxiety }\end{array}$ & 65 \\
\hline 9. & $\begin{array}{l}\text { Rheum } \\
\text { tanguticum } \\
\text { Family - } \\
\text { Polygonaceae }\end{array}$ & Roots & Polysaccharide & $\begin{array}{l}\text { There is a decrease in } \\
\text { the white blood cells. } \\
\text { This decreases the } \\
\text { ulcerative area and the } \\
\text { weight of colon. }\end{array}$ & $\begin{array}{l}\text { Purgation } \\
\text { Antibacterial } \\
\text { Antipyretic } \\
\text { Haemostatic effects } \\
\text { Antineoplastic } \\
\text { Immune activity }\end{array}$ & 66 \\
\hline 10. & $\begin{array}{l}\text { Polygonum } \\
\text { tinctorium } \\
\text { Family - } \\
\text { Polygonaceae }\end{array}$ & $\begin{array}{l}\text { Leaves, stem } \\
\text { and shrubs }\end{array}$ & $\begin{array}{l}\text { The major } \\
\text { constituent is } \\
\text { Tryptanthrin. }\end{array}$ & $\begin{array}{l}\text { Reduced interleukins } \\
\text { decreases the nuclear } \\
\text { factor gamma and } \\
\text { causes the colon } \\
\text { damage to lessen. }\end{array}$ & $\begin{array}{l}\text { Antidote } \\
\text { Anti-inflammatory } \\
\text { Antipyretic } \\
\text { Depurative } \\
\text { Treatment of } \\
\text { freckles, pimples, } \\
\text { mumps, thrush, } \\
\text { infantile convulsions } \\
\text { in children }\end{array}$ & 67 \\
\hline 11. & $\begin{array}{l}\text { Zingiber } \\
\text { zerumbet } \\
\text { Family - } \\
\text { Zingiberaceae }\end{array}$ & Rhizomes & $\begin{array}{l}\text { Zerumbone } \\
\text { (asesquiterpenoid) }\end{array}$ & 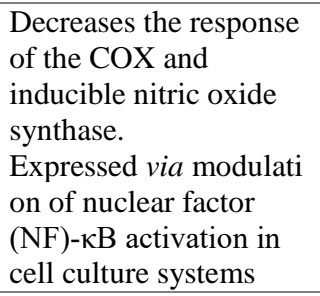 & $\begin{array}{l}\text { Anti-growth } \\
\text { property in certain } \\
\text { cancer cell lines } \\
\text { Anti-inflammatory } \\
\text { property in several } \\
\text { human cancer cell } \\
\text { lines }\end{array}$ & 68 \\
\hline 12. & $\begin{array}{l}\text { Andrographis } \\
\text { Paniculata } \\
\text { Family - } \\
\text { Acanthaceae }\end{array}$ & Extract & $\begin{array}{l}\text { The main } \\
\text { constituents - } \\
\text { diterpenes lactones } \\
\text { and } \\
\text { andrographolide. }\end{array}$ & $\begin{array}{l}\text { Considerable reduction } \\
\text { in the mean CRP level } \\
\text { lead to the treatment of } \\
\text { the CD. }\end{array}$ & $\begin{array}{l}\text { Herbal remedy } \\
\text { Treat upper } \\
\text { respiratory tract } \\
\text { infections }\end{array}$ & 69 \\
\hline 13. & $\begin{array}{l}\text { Aloe vera } \\
\text { Family - } \\
\text { Asphodelaceae }\end{array}$ & $\begin{array}{l}\text { Mucous } \\
\text { extracted from } \\
\text { the leaves of } \\
\text { aloe vera. }\end{array}$ & Aloe gel & $\begin{array}{l}\text { In vitro study, reduced } \\
\text { secretions of } \\
\text { prostaglandins E2 and } \\
\text { interlukins- } 18 \text {. } \\
\text { In vivo study, reduced } \\
\text { TNF - alpha. }\end{array}$ & $\begin{array}{l}\text { Anti-inflammatory } \\
\text { Treatment of IBD } \\
\text { Reduced secretions } \\
\text { of prostaglandins E2 } \\
\text { and interlukins-18 } \\
\text { Anti-microbial effect }\end{array}$ & 70 \\
\hline 14. & $\begin{array}{l}\begin{array}{l}\text { Glycyrrhiza } \\
\text { glabra } \\
\text { (Liquorice) }\end{array} \\
\text { Family - } \\
\text { Leguminosae }\end{array}$ & $\begin{array}{l}\text { Root of the } \\
\text { plant }\end{array}$ & $\begin{array}{l}\text { Glycyrrhizin } \\
\text { extracted from } \\
\text { liquorice. }\end{array}$ & $\begin{array}{l}\text { Diammonium } \\
\text { Glycyrrhizinate are to } \\
\text { treat the CD. It } \\
\text { decreases the NF- } \kappa B \text {, } \\
\text { TNF- } \alpha \text {, and ICAM-1 in } \\
\text { the swelled mucosa. } \\
\text { The mineralocorticoid } \\
\text { effect is exerted by } \\
\text { inhibition of } 11 \mathrm{~b}- \\
\text { hydroxysteroid } \\
\text { dehydrogenase. It }\end{array}$ & $\begin{array}{l}\text { Used as an artificial } \\
\text { sweetener } \\
\text { Immune modulatory } \\
\text { Adaptogenic } \\
\text { property } \\
\text { Estrogenic activity } \\
\text { has also been } \\
\text { reported for } \\
\text { liquorice and is } \\
\text { attributed to its } \\
\text { isoflavone }\end{array}$ & 71 \\
\hline
\end{tabular}


Table 1. Plants used in treatment of Crohn's Disease. (cont.)

\begin{tabular}{|c|c|c|c|c|c|c|}
\hline $\begin{array}{l}\text { Sr. } \\
\text { no. }\end{array}$ & Botanical name & Part of plant & $\begin{array}{l}\text { Extract / } \\
\text { constituents }\end{array}$ & MOA & Use & Ref. \\
\hline & & & & $\begin{array}{l}\text { decreases the plasma } \\
\text { renin activity and } \\
\text { aldosterone secretion. }\end{array}$ & $\begin{array}{l}\text { constituents. } \\
\text { Chemo preventive } \\
\text { effects }\end{array}$ & \\
\hline 15. & $\begin{array}{l}\text { Slippery Elm } \\
\text { (Ulmus rubra) } \\
\text { Family - } \\
\text { Ulmaceae }\end{array}$ & $\begin{array}{l}\text { Powdered bark } \\
\text { of the slippery } \\
\text { elm tree. }\end{array}$ & $\begin{array}{l}\text { It contains } \\
\text { polysaccharides } \\
\text { as pentoses, } \\
\text { methyl-pentoses, } \\
\text { and hexoses. } \\
\text { The bark has high } \\
\text { conc. of } \\
\text { antioxidant as } \\
\text { beta-sitosterol, } \\
\text { traces of beta- } \\
\text { carotene, and } \\
\text { flavonoids. }\end{array}$ & $\begin{array}{l}\text { Slippery Elm was } \\
\text { suggested to be } \\
\text { effective for treating } \\
\text { IBD patients owing to } \\
\text { its antioxidant effects. } \\
\text { However, further } \\
\text { studies are needed to } \\
\text { confirm its efficacy. }\end{array}$ & $\begin{array}{l}\text { Treat cough, } \\
\text { diarrhoea, and other } \\
\text { GI complaints } \\
\text { Antioxidant effects } \\
\text { Treatment for sore } \\
\text { throat, coughs, } \\
\text { dryness of the lungs, } \\
\text { inflammation of the } \\
\text { skin inflammations, } \\
\text { wounds, and } \\
\text { irritation of the } \\
\text { digestive tract }\end{array}$ & 72 \\
\hline 16. & $\begin{array}{l}\begin{array}{l}\text { Potentilla } \\
\text { tormentilla } \\
\text { (Tormentil) }\end{array} \\
\text { Family - } \\
\text { Rosaceae }\end{array}$ & $\begin{array}{l}\text { Powder of } \\
\text { roots }\end{array}$ & $\begin{array}{l}\text { This consists of } \\
\text { Tannins and } 18 \% \\
\text { Tormentil red. } \\
\text { Along with } \\
\text { Protocatehuic acid, } \\
\text { Phloroglucin, } \\
\text { Resin, Ellagic and } \\
\text { kinovic acids }\end{array}$ & $\begin{array}{l}\text { Tormentil is effective } \\
\text { in treatment of } \\
\text { diarrhoea or intestinal } \\
\text { inflammation. In } \\
\text { vitro studies have } \\
\text { verified that the anti- } \\
\text { inflammatory, anti- } \\
\text { oxidative, and bacterial } \\
\text { growth regulatory } \\
\text { effects of Tormentil } \\
\text { extracts are beneficial } \\
\text { to use. }\end{array}$ & $\begin{array}{l}\text { Anti-inflammatory } \\
\text { effect } \\
\text { Treats diarrhoea } \\
\text { Anti-oxidant effect } \\
\text { Astringent } \\
\text { Supports bowels } \\
\text { and divulges } \\
\text { nourishment to } \\
\text { them }\end{array}$ & 73 \\
\hline 17. & $\begin{array}{l}\text { Wheat Grass } \\
\text { (Triticum } \\
\text { aestivum) } \\
\text { Family - } \\
\text { Poaceae }\end{array}$ & $\begin{array}{l}\text { Fresh juice } \\
\text { from the plant }\end{array}$ & $\begin{array}{l}\text { Its major } \\
\text { component is } \\
\text { chlorophyll and it } \\
\text { forms } 70 \% \text { of the } \\
\text { composition, It } \\
\text { holds surplus of } \\
\text { vitamins, minerals, } \\
\text { amino acids and } \\
\text { vital enzymes like } \\
\text { superoxide } \\
\text { dismutase and } \\
\text { cytochrome oxidase. }\end{array}$ & $\begin{array}{l}\text { The consumption of } \\
\text { fresh wheat juice on } \\
\text { bare stomach proves to } \\
\text { be an efficient } \\
\text { treatment. In some } \\
\text { randomized controlled } \\
\text { trial with a small } \\
\text { sample size showed } \\
\text { that wheat juice yielded } \\
70 \% \text { progress in IBD } \\
\text { patients devoid of any } \\
\text { serious side effects. } \\
\text { The most noteworthy } \\
\text { trait of wheatgrass juice } \\
\text { is its high chlorophyll } \\
\text { content. Chlorophyll } \\
\text { has structural } \\
\text { similarities to } \\
\text { haemoglobin and is } \\
\text { said to restore or also } \\
\text { enact as alternative of } \\
\text { haemoglobin in } \\
\text { haemoglobin } \\
\text { deficiency conditions. }\end{array}$ & $\begin{array}{l}\text { Anti-allergic and } \\
\text { anti-Asthmatic } \\
\text { treatment } \\
\text { Anticancer } \\
\text { treatment by the } \\
\text { help of the enzymes } \\
\text { present in it } \\
\text { Naturally occurring } \\
\text { antioxidant } \\
\text { Used for treating } \\
\text { clinical condition } \\
\text { like thalassemia and } \\
\text { hemolyticanemia }\end{array}$ & 74 \\
\hline 18. & $\begin{array}{l}\begin{array}{l}\text { Coriolus } \\
\text { versicolor }\end{array} \\
\text { Family - } \\
\text { Polyporaceae }\end{array}$ & $\begin{array}{l}\text { Medicinal } \\
\text { mushroom on } \\
\text { Tree trunks are } \\
\text { used. }\end{array}$ & $\begin{array}{l}\text { It contains } \\
\text { polysaccharopeptide } \\
\text { (PSP), proteins, } \\
\text { amino acids, and } \\
\text { other various } \\
\text { bioactive } \\
\text { substances. }\end{array}$ & $\begin{array}{l}\text { For a, dextran sulphate } \\
\text { sodium (DSS)- } \\
\text { stimulated colitis } \\
\text { prototype, the extract } \\
\text { decreased pro- } \\
\text { inflammatory cytokines, } \\
\text { including TNF- } \alpha \text {, IL- } \\
1 \beta \text {, and IL-6. } \\
\text { It decreases signal } \\
\text { transducers and } \\
\text { activators of } \\
\text { transcription } 1\end{array}$ & $\begin{array}{l}\text { Immunological } \\
\text { enhancement } \\
\text { Antiulcer activity } \\
\text { Liver protecting } \\
\text { Oxidation } \\
\text { resistance } \\
\text { Reducing blood fat } \\
\text { Used for treating } \\
\text { cancer, hepatitis, } \\
\text { hyperlipidaemia, } \\
\text { chronic bronchitis } \\
\text { and other diseases. }\end{array}$ & 75 \\
\hline
\end{tabular}


Table 1. Plants used in treatment of Crohn's Disease. (cont.)

\begin{tabular}{|c|c|c|c|c|c|c|}
\hline $\begin{array}{l}\text { Sr. } \\
\text { no. }\end{array}$ & Botanical name & Part of plant & $\begin{array}{l}\text { Extract / } \\
\text { constituents }\end{array}$ & MOA & Use & Ref. \\
\hline & & & & $\begin{array}{l}\text { (STAT1) and STAT6 } \\
\text { molecules, which } \\
\text { further leads to decreased } \\
\text { interferon-gamma } \\
(\text { IFN- } \gamma) \text { and IL-4. }\end{array}$ & & \\
\hline 19. & $\begin{array}{l}\text { Inonotus obliquus } \\
\text { (Chaga) } \\
\text { Family - } \\
\text { Hymenochaetaceae }\end{array}$ & $\begin{array}{l}\text { Parasitic } \\
\text { mushroom } \\
\text { from branches } \\
\text { of birch trees. }\end{array}$ & $\begin{array}{l}\text { It comprises of } \\
\text { steroids and also } \\
\text { has polyphenolic, } \\
\text { triterpenoids, } \\
\text { lanosterol, } \\
\text { inotodiol, } \\
\text { trametenolic acids } \\
\text { and ergosterol } \\
\text { peroxides. }\end{array}$ & $\begin{array}{l}\text { The aqueous extract of } \\
\text { Inonotus Obliquus had } \\
\text { prominently lessened } \\
\text { (DSS)- stimulated } \\
\text { iNOS levels and } \\
\text { myeloperoxidase build- } \\
\text { up in colon tissues. } \\
\text { Restraining of TNF- } \alpha \\
\text { and iNOS along with } \\
\text { IL-1 } \beta \text { by aqueous } \\
\text { extract of Inonotus } \\
\text { Obliquus symbolizes it } \\
\text { as an important } \\
\text { supplement to cure IBD. }\end{array}$ & $\begin{array}{l}\text { Anti-inflammatory } \\
\text { Anti-tumour } \\
\text { Anti-parasitic effect } \\
\text { Immune- } \\
\text { modulating } \\
\text { Hypercholesterolemia } \\
\text { Anti-bacterial }\end{array}$ & 76 \\
\hline 20. & $\begin{array}{l}\text { Prunus mume } \\
\text { Family - } \\
\text { Rosaceae }\end{array}$ & $\begin{array}{l}\text { The smoked } \\
\text { and dried fruit } \\
\text { is used. }\end{array}$ & $\begin{array}{l}\text { The six constituents } \\
\text { isolated from } \\
\text { Prunus Mume were } \\
\text { 5-hydroxymethyl- } \\
\text { 2-furalehyde, 4-o- } \\
\text { caffeoylquinic acid } \\
\text { methyl ester, } \\
\text { benzyl-o-beta-D- } \\
\text { glucopyranoside } \\
\text { and liquiritigenin- } \\
\text { 7-o-beta-D- } \\
\text { glucopyranoside. } \\
\text { 2-furaldehyde (1), } \\
\text { 4-O-caffeoylquinic } \\
\text { acid methyl ester } \\
\text { (2), prunasin (3), } \\
\text { 5-O-caffeoylquinic } \\
\text { acid methyl ester (4), } \\
\text { benzyl-O- } \beta \text {-D- } \\
\text { glucopyranoside } \\
\text { (5), and liquiritigenin- } \\
\text { 7-O- } \beta-D- \\
\text { glucopyranosi. }\end{array}$ & $\begin{array}{l}\text { It mends the colitis and } \\
\text { setbacks the large } \\
\text { intestine injury. } \\
\text { It also mend the } \\
\text { irregular cytokine } \\
\text { secretion. } \\
\text { It decreases the TNF- } \alpha \text {, } \\
\text { COX- } 2 \text {, INF- } \gamma \text { in the } \\
\text { DSS model. }\end{array}$ & $\begin{array}{l}\text { Used as a Korean } \\
\text { ancient remedy for } \\
\text { fever, coughing, } \\
\text { and intestinal } \\
\text { diseases } \\
\text { Reduce the virus } \\
\text { infection } \\
\text { Antioxidant } \\
\text { activities }\end{array}$ & 77 \\
\hline 21. & $\begin{array}{l}\begin{array}{l}\text { Zingiber } \\
\text { officinale } \\
\text { (Ginger) }\end{array} \\
\text { Family - } \\
\text { Zingiberaceae }\end{array}$ & $\begin{array}{l}\text { The rhizomes } \\
\text { of ginger is } \\
\text { used. }\end{array}$ & $\begin{array}{l}\text { It comprises of } \\
\text { several } \\
\text { components - } \\
\text { gingerols, } \\
\text { shogaols, paradols, } \\
\text { volatile } \\
\text { constituents like } \\
\text { sesquiterpenes and } \\
\text { monoterpenes. }\end{array}$ & $\begin{array}{l}\text { The prototype which is } \\
\text { stimulated with } \\
\text { enteritis is seen to be } \\
\text { cured on consuming } \\
\text { ginger extract. } \\
\text { It decreases the NF-kB } \\
\text { activity and IL-1 } \beta \\
\text { protein concentration in } \\
\text { the large intestine. }\end{array}$ & $\begin{array}{l}\text { Anti-oxidant effects } \\
\text { Anti-inflammatory } \\
\text { potential } \\
\text { Used as a spice } \\
\text { Used for treating } \\
\text { diabetes mellitus } \\
\text { Reduces } \\
\text { cardiovascular } \\
\text { disorder } \\
\text { Health-enhancing } \\
\text { assessment }\end{array}$ & 78 \\
\hline 22. & $\begin{array}{l}\text { Garcinia } \\
\text { cambogia } \\
\text { Family - } \\
\text { Rubiaceae }\end{array}$ & $\begin{array}{l}\text { It's fruit } \\
\text { extract is used. }\end{array}$ & $\begin{array}{l}\text { It consists of } \\
\text { calcium salt of } \\
\text { hydroxy citric acid } \\
\text { (HCA), maleic } \\
\text { acid, Xanthones } \\
\text { and Garcinol. }\end{array}$ & $\begin{array}{l}\text { It causes the decrease } \\
\text { in MPO activity, COX- } \\
2 \text { and iNOS-expression. } \\
\text { It decreases the } \\
\text { prostaglandins levels } \\
\text { and IL-2 beta colonic } \\
\text { levels. } \\
\text { It is seen that there is } \\
\text { reduction in DNA } \\
\text { damage. }\end{array}$ & $\begin{array}{l}\text { Anti-inflammatory } \\
\text { Gastroprotective } \\
\text { effects } \\
\text { Anti-ulcer activity } \\
\text { Dietary supplement }\end{array}$ & 79 \\
\hline
\end{tabular}


Table 1. Plants used in treatment of Crohn's Disease. (cont.)

\begin{tabular}{|c|c|c|c|c|c|c|}
\hline $\begin{array}{l}\text { Sr. } \\
\text { no. }\end{array}$ & Botanical name & Part of plant & $\begin{array}{l}\text { Extract / } \\
\text { constituents }\end{array}$ & MOA & Use & Ref. \\
\hline 23. & $\begin{array}{l}\text { Green Tea } \\
\text { Family - } \\
\text { Theaceae }\end{array}$ & $\begin{array}{l}\text { The leaves } \\
\text { from Camellia } \\
\text { sinensis is } \\
\text { used. }\end{array}$ & $\begin{array}{l}\text { It consists of } \\
\text { Catechin, } \\
\text { polyphenols, } \\
\text { caffeine, amino } \\
\text { acids and other } \\
\text { components as } \\
\text { vitamins, theanine, } \\
\text { carbohydrates and } \\
\text { lipids. }\end{array}$ & $\begin{array}{l}\text { Catechin present in tea } \\
\text { reduces NF-kB activity, } \\
\text { also decreases the } \\
\text { concentration of } \\
\text { inflammatory } \\
\text { mediators. } \\
\text { There is obstruction to } \\
\text { generation of TNF- } \\
\text { alpha, IFN- } \gamma \text {, } \\
\text { prostaglandins in the } \\
\text { intestinal mucosa } \\
\text { membrane. }\end{array}$ & $\begin{array}{l}\text { It is used for } \\
\text { cardiac health } \\
\text { improvement. } \\
\text { It treats arthritis. } \\
\text { Increases the bone } \\
\text { density } \\
\text { Anti-viral property } \\
\text { Anti-carcinogenic } \\
\text { property }\end{array}$ & 80 \\
\hline 24. & $\begin{array}{l}\text { Bacopa monnieri } \\
\text { (Brahmi) } \\
\text { Family - } \\
\text { Umbelliferae }\end{array}$ & $\begin{array}{l}\text { The fresh and } \\
\text { dried herbs, } \\
\text { leaves and } \\
\text { stems of } \\
\text { Centrallaasiati } \\
\text { ca Urban are } \\
\text { used. }\end{array}$ & $\begin{array}{l}\text { It consists of } \\
\text { Brahmin } \\
\text { (alkaloid), a } \\
\text { mixture of } 3 \\
\text { alkaloid (saponin, } \\
\text { Bacoside A and B). } \\
\text { It also has Beutalic } \\
\text { acid, Stigmasterol, } \\
\text { monnierin, } \\
\text { hersaponin. }\end{array}$ & $\begin{array}{l}\text { It has an immune- } \\
\text { modulatory effect as it } \\
\text { increases the immune } \\
\text { function as by lowering } \\
\text { the IgA and IgG } \\
\text { (immunoglobulins) in } \\
\text { the model used. }\end{array}$ & $\begin{array}{l}\text { Used as nervine } \\
\text { tonic } \\
\text { Treats epilepsy } \\
\text { Laxative use } \\
\text { Also used as } \\
\text { diuretic } \\
\text { Alcoholic extract } \\
\text { has anti-cancer } \\
\text { properties }\end{array}$ & 81 \\
\hline 25. & $\begin{array}{l}\text { Patriniascabiosae } \\
\text { folia } \\
\text { Family - } \\
\text { Valerianaceae }\end{array}$ & $\begin{array}{l}\text { Essential oil } \\
\text { was used. }\end{array}$ & $\begin{array}{l}\text { Its major } \\
\text { constituent is: } \\
\text { caryophyllene } \\
\text { oxide, } \\
\text { caryophyllene, } \alpha \text { - } \\
\text { caryophyllene, } \beta \text { - } \\
\text { damascenone, } \\
\text { calarene, and } \\
\text { phenol. }\end{array}$ & $\begin{array}{l}\text { It reduced the decrease } \\
\text { in colon length, } \\
\text { expansion of spleen } \\
\text { dia. } \\
\text { It also lessened the } \\
\text { abnormal secretions } \\
\text { and mRNA expressions } \\
\text { in model. }\end{array}$ & $\begin{array}{l}\text { Anti-inflammatory } \\
\text { Treats colonic } \\
\text { inflammations } \\
\text { Virus infections } \\
\text { Treats diarrhoea } \\
\text { and gastric bleeding } \\
\text { Infiltrates the } \\
\text { immune cells }\end{array}$ & 82 \\
\hline
\end{tabular}

\section{CONCLUSION}

Noteworthy development has been accomplished in a thoughtful, supportive and a considerate way for the advancement of capability to distinguish/identify/discover and to cure/ heal and provide medication for $\mathrm{CD}$. The forthcoming potential of $\mathrm{CD}$ is controlling latest/recent therapeutic treatments and innovative biomarkers to forecast scientific consequences and develop therapeutic and clinical remedies more successfully ${ }^{14}$.

All the accessible records relating to the processing of extracts obtained from plants and herbals provide the gastroenterologists with the description to the patients towards the welfares of the treatment of Crohn's disease. Alongside, gives verified documents and evidence for their utilization. Pharmaceutical industries need assistance to modern/ up-to-date information by auxiliary pertinent trainings, also if their economical profit is ought to be significantly dropped as associated with supplementary type of therapies. The worldwide medical organizations and government administration must seize the occasions accessible locally in an extreme fundamental way for the drugs development/ processing by economically reinforcing the appropriate scientific research. The issue for the present time is that expense for treating the patients with $\mathrm{CD}$ is escalating promptly. Such that, the herbal medications here possibly willed note towards a new-fangled, effectual and low-cost therapy or healing procedure. Medical practitioner have to be broad-minded and are much more liberal and indulgent when it comes to merits of alternate medicine. In conclusion, it is necessary for crucial, fundamental portrayal of alternate medicine in the medical science courses of under-graduates and post-graduates ${ }^{20}$.

The nutritional therapy has now become a basic remedy for active $\mathrm{CD}$, with modest development in its action. Even the efficient diet remedy helps in lowering number of infectious and dietary mediators ${ }^{89}$.

A amalgation of signs and mucosal curing has been anticipated as the aim for the CD treatment. The usage of corticosteroids and thiopurines persist as backbone for cure ${ }^{90}$. These enquiries are vital not only for evolving innovative medication policies comprising the assortment of the precise objectives to ideally succeed $\mathrm{IBD}^{91}$. 
There are immobile indefinite queries on pathophysiology, disease behaviour, and intestinal inflammation handlers in diverse IBD patient that need advance evaluation. With this information, there must be aptitude to refurbish innovative modified cure for IBD patients ${ }^{92}$.

\section{ACKNOWLEDGMENTS}

The authors are grateful to Dr. Madhu Chitkara, Vice Chancellor, Chitkara University, Rajpura, Patiala, India and Ashok Chitkara, Chancellor, Chitkara University, Rajpura, Patiala, India, for support and institutional facilities.

\section{Conflict of interest}

The authors declare no conflict of interest, financial or otherwise.

\section{Funding}

None to declared.

\section{Ethics approval}

Not applicable.

\section{Article info:}

Received April 25, 2020

Received in revised form July 25, 2020

Accepted July 27, 2020

\section{REFERENCES}

1. Pithadia $A B$, Jain $S$. Treatment of inflammatory bowel disease (IBD). Pharmacol Rep. 2011;63(3):629-42.

2. Binder V, Hendriksen C, Kreiner S. Prognosis in Crohn's disease--based on results from a regional patient group from the county of Copenhagen. Gut. 1985;26(2):146-50.

3. Ha F, Khalil H. Crohn's disease: A clinical update. Therap Adv Gastroenterol. 2015;8(6):352-9.

4. Gajendran M, Loganathan P, Catinella AP, Hashash JG. A comprehensive review and update on Crohn's disease, 2018;64(2):20-57.

5. Aufses AH Jr. The history of Crohn's disease. Surg Clin North Am. 2001;81(1):1-11.

6. De Cruz P, Kamm MA, Hamilton AL, et al. Crohn's disease management after intestinal resection: A randomised trial. Lancet. 2015;385(9976):1406-17.

7. Adamiak T, Walkiewicz-Jedrzejczak D, Fish D, et al. : Incidence, clinical characteristics, and natural history of pediatric IBD in Wisconsin: a population-based epidemiological study. Inflamm Bowel Dis. 2013;19(6):1218-23.

8. Baert F, Moortgat L, Van Assche G, et al. Mucosal healing predicts sustained clinical remission in patients with early-stage Crohn's disease. Gastroenterology. 2010;138(2):463-68.

9. Abraham BP, Ahmed T, Ali T. Inflammatory Bowel Disease: Pathophysiology and Current Therapeutic Approaches. Handb Exp Pharmacol. 2017;239:115-46.

10. Tsianos EV, Katsanos KH, Tsianos VE. Role of genetics in the diagnosis and prognosis of Crohn's disease. World J Gastroenterol. 2012;18(2):105-18.

11. Segal AW. Making sense of the cause of Crohn's - a new look at an old disease. F1000Res. 2016;5:2510.

12. Rieder F, Zimmermann EM, Remzi FH, Sandborn WJ. Crohn's disease complicated by strictures: A systematic review. Gut. 2013;62(7):1072-84.

13. Scharl M, Rogler G. Pathophysiology of fistula formation in Crohn's disease. World J Gastrointest Pathophysiol. 2014;5(3):205-12.

14. Tozer PJ, Lung P, Lobo AJ, et al. Review article: Pathogenesis of Crohn's perianal fistula-understanding factors impacting on success and failure of treatment strategies. Aliment Pharmacol Ther. 2018;48(3):260-9.

15. Thoreson R, Cullen JJ. Pathophysiology of inflammatory bowel disease: An overview. Surg Clin North Am. 2007; 87(3):575-85.

16. Roccarina D, Garcovich M, Ainora ME, et al. Diagnosis of bowel diseases: The role of imaging and ultrasonography. World J Gastroenterol. 2013;19(14):2144-53.

17. Ruthruff B. Clinical review of Crohn's disease. J Am Acad Nurse Pract. 2007;19(8):392-7.

18. Rutgeerts P, Geboes K, Vantrappen G, Kerremans R, Coenegrachts JL, Coremans G. Natural history of recurrent Crohn's disease at the ileocolonic anastomosis after curative surgery. Gut. 1984;25(6):665-72.

19. Pigneur B, Seksik P, Viola S, et al. Natural history of Crohn's disease: Comparison between childhood- and adult -onset disease. Inflamm Bowel Dis. 2010;16(6):953-61.

20. Vermeire S, van Assche G, Rutgeerts P. Review article: Altering the natural history of Crohn's disease--evidence for and against current therapies. Aliment Pharmacol Ther. 2007;25(1):3-12.

21. Triantafyllidi A, Xanthos T, Papalois A, Triantafillidis JK. Herbal and plant therapy in patients with inflammatory bowel disease. Ann Gastroenterol. 2015;28(2):210-20.

22. Fichtner-Feigl S, Young CA, Kitani A, Geissler EK, Schlitt HJ, Strober W. IL-13 signaling via IL-13R alpha2 induces major downstream fibrogenic factors mediating fibrosis in chronic TNBS colitis. Gastroenterology. 2008; 135(6):2003-13.e20137.

23. Bernstein C., Wajda A., Blanchard J. The clustering of other chronic inflammatory diseases in inflammatory bowel disease: A population-based study. Gastroenterology. 2005;129:827-36.

24. Pedersen J, Coskun M, Soendergaard C, Salem M, Nielsen OH. Inflammatory pathways of importance for management of inflammatory bowel disease. World J Gastroenterol. 2014;20(1):64-77.

25. Newsroom. Vaccine hope to treat Crohn's disease is one step closer. Edinburgh News. 15 March, 2019. https://www. edinburghnews.scotsman.com/health/vaccine-hope-treatCrohns-disease-one-step-closer-72958.

26. Korzenik JR. Is Crohn's disease due to defective immunity?. Gut. 2007;56(1):2-5.

27. Solomon MJ. Fistulae and abscesses in symptomatic perianal Crohn's disease. Int J Colorectal Dis. 1996; 11(5):222-6.

28. Ashton JJ, Gavin J, Beattie RM: Exclusive enteral nutrition in Crohn's disease: Evidence and practicalities. Clin Nutr. 2019;38(1):80-9.

29. Liu F, Ma R, Riordan SM, et al. Azathioprine, mercaptopurine, and 5-aminosalicylic acid affect the growth of IBD-associated Campylobacter species and other enteric microbes. Front Microbiol. 2017;8:527.

30. Frei SM, Pesch T, Lang S, et al. A role for tumor necrosis factor and bacterial antigens in the pathogenesis of Crohn's disease-associated fistulae. Inflamm Bowel Dis. 2013;19(13):2878-87.

31. Greenbloom SL, Steinhart AH, Greenberg GR. 
Combination ciprofloxacin and metronidazole for active Crohn's disease. Can J Gastroenterol. 1998;12(1):53-6.

32. Ganji AM, Rafieian KM. Phytotherapies in inflammatory bowel disease. J Res Med Sci. 2019;24:42.

33. Nielsen OH, Vainer B, Rask-Madsen J. Review article: The treatment of inflammatory bowel disease with 6-mercaptopurine or azathioprine. Aliment Pharmacol Ther. 2001;15(11):1699-1708.

34. Cuffari C, Théorêt Y, Latour S, Seidman G. 6Mercaptopurine metabolism in Crohn's disease: Correlation with efficacy and toxicity. Gut. 1996;39(3):401-6.

35. Bostrom B, Erdmann G. Cellular pharmacology of 6mercaptopurine in acute lymphoblastic leukemia. Am J Pediatr Hematol Oncol. 1993;15(1):80-6.

36. Tremaine WJ. Refractory IBD: Medical management. Neth J Med. 1997;50(2):S12-4.

37. Sandborn WJ. A review of immune modifier therapy for inflammatory bowel disease: Azathioprine, 6-mercaptopurine, cyclosporine, and methotrexate. Am J Gastroenterol. 1996;91(3):423-33.

38. Rahman LK, Chhabra SR. The chemistry of methotrexate and its analogues. Med Res Rev. 1988;8(1):95-155.

39. van Dieren JM, Kuipers EJ, Samsom JN, Nieuwenhuis EE, van der Woude CJ. Revisiting the immunomodulators tacrolimus, methotrexate, and mycophenolate mofetil: their mechanisms of action and role in the treatment of IBD. Inflamm Bowel Dis. 2006;12(4):311-27.

40. Ardizzone S, Bollani S, Manzionna G, Imbesi V, Colombo E, Bianchi Porro G. Comparison between methotrexate and azathioprine in the treatment of chronic active Crohn's disease: A randomised, investigator-blind study. Dig Liver Dis. 2003;35(9):619-27.

41. Shen DD, Azarnoff DL. Clinical pharmacokinetics of methotrexate. Clin Pharmacokinet. 1978;3(1):1-13.

42. Fraser AG. Methotrexate: First-line or second-line immunomodulator?. Eur J Gastroenterol Hepatol. 2003; 15(3):225-31.

43. Schröder O, Stein J. Low dose methotrexate in inflammatory bowel disease: Current status and future directions. Am J Gastroenterol. 2003;98(3):530-7.

44. Hanauer SB, Sandborn WJ, Rutgeerts P, et al. Human anti-tumor necrosis factor monoclonal antibody (adalimumab) in Crohn's disease: The CLASSIC-I trial. Gastroenterology. 2006;130(2):323-591.

45. Regueiro M, Schraut W, Baidoo L, et al. Infliximab prevents Crohn's disease recurrence after ileal resection. Gastroenterology. 2009;136(2):441-716.

46. Papadakis KA, Targan SR. Tumor necrosis factor: Biology and therapeutic inhibitors. Gastroenterology. 2000;119(4):1148-57.

47. Kawalec P, Mikrut A, Wiśniewska N, Pilc A. Tumor necrosis factor- $\alpha$ antibodies (infliximab, adalimumab and certolizumab) in Crohn's disease: Systematic review and meta-analysis. Arch Med Sci. 2013;9(5):765-79.

48. Sandborn WJ, Feagan BG, Stoinov S, et al. Certolizumab pegol for the treatment of Crohn's disease. N Engl J Med. 2007;357(3):228-38.

49. Cheifetz A, Smedley M, Martin S, et al. The incidence and management of infusion reactions to infliximab: A large center experience. Am J Gastroenterol. 2003;98(6): 1315-24.

50. Sandborn WJ, Hanauer SB. Infliximab in the treatment of Crohn's disease: A user's guide for clinicians. Am J Gastroenterol. 2002;97(12):2962-72.

51. Roach DR, Bean AG, Demangel C, France MP, Briscoe $\mathrm{H}$, Britton WJ. TNF regulates chemokine induction essential for cell recruitment, granuloma formation, and clearance of mycobacterial infection. J Immunol. 2002; 168(9):4620-7.

52. Thalayasingam N, Isaacs JD. Anti-TNF therapy. Best Pract Res Clin Rheumatol. 2011;25(4):549-67.

53. Tracey D, Klareskog L, Sasso EH, Salfeld JG, Tak PP. Tumor necrosis factor antagonist mechanisms of action: A comprehensive review. Pharmacol Ther. 2008;117(2): 244-79.

54. Van den Brande JM, Braat H, van den Brink GR, et al. Infliximab but not etanercept induces apoptosis in lamina propria T-lymphocytes from patients with Crohn's disease. Gastroenterology. 2003;124(7):1774-85.

55. Cassinotti Andrea, Ardizzone Sandro and Porro Gabriele Bianchi. Adalimumab for the treatment of Crohn's disease. Biologics. 2008;2(4):763-77.

56. Asgharpour A, Cheng J, Bickston SJ. Adalimumab treatment in Crohn's disease: An overview of long-term efficacy and safety in light of the EXTEND trial. Clin Exp Gastroenterol. 2013;6:153-60.

57. Kaliora AC, Stathopoulou MG, Triantafillidis JK, Dedoussis GV, Andrikopoulos NK. Chios mastic treatment of patients with active Crohn's disease. World J Gastroenterol. 2007;13(5):748-53.

58. Krebs S, Omer TN, Omer B. Wormwood (Artemisia absinthium) suppresses tumour necrosis factor alpha and accelerates healing in patients with Crohn's disease - A controlled clinical trial. Phytomedicine. 2010;17(5):305-9.

59. Schicho R, Storr M. Cannabis finds its way into treatment of Crohn's disease. Pharmacology. 2014;93(1-2):1-3.

60. Esposito G, Filippis DD, Cirillo C, et al. Cannabidiol in inflammatory bowel diseases: A brief overview. Phytother Res. 2013;27(5):633-6.

61. Johnson Jon, Lindsay Slowiczek. What to know about boswellia? Medical News Today. 2019.

62. Sun J, Shen X, Dong J, et al. Tripterygium wilfordii Hook $\mathrm{F}$ as maintenance treatment for Crohn's disease. Am J Med Sci. 2015;350(5):345-51.

63. Holt PR, Katz S, Kirshoff R. Curcumin therapy in inflammatory bowel disease: A pilot study. Dig Dis Sci. 2005;50(11):2191-3.

64. Parmar VS, Sharma SK and Poonam. Novel constituents of Gardenia species - a review. J Sci Ind Res. 2000;59:893903.

65. Chopade VV, Phatak AA, Upaganlawar AB and Tankar AA. Green Tea (Camellia sinensis): Chemistry, traditional, medicinal uses and its pharmacological activities - a review. Pharmacognosy reviews. 2008;2(3): 157-62.

66. Liu L, Mei QB, Wang ZP, et al. The effects of Rheum tanguticum polysaccharide on the polarization of Th1 and Th2 cells in TNBS-induced colitis in murine. Int $\mathrm{J}$ Biomed Sci. 2005;1(1):23-32.

67. Micallef MJ, Iwaki K, Ishihara T, et al. The natural plant product tryptanthrin ameliorates dextran sodium sulfateinduced colitis in mice. Int Immunopharmacol. 2002;2(4): 565-78.

68. Murakami A, Hayashi R, Tanaka T, Kwon KH, Ohigashi H, Safitri R. Suppression of dextran sodium sulfate-induced colitis in mice by zerumbone, a subtropical ginger sesquiterpene, and nimesulide: Separately and in combination. Biochem Pharmacol. 2003;66(7):1253-61.

69. Sandborn WJ, Targan SR, Byers VS, et al. Andrographis paniculata extract (HMPL-004) for active ulcerative colitis. Am J Gastroenterol. 2013;108(1):90-8.

70. Langmead L, Makins RJ, Rampton DS. Antiinflammatory effects of aloe vera gel in human colorectal mucosa in vitro. Aliment Pharmacol Ther. 2004;19(5): 521-7. 
71. Yuan H, Ji WS, Wu KX, Jiao JX, Sun LH, Feng YT. Anti-inflammatory effect of Diammonium Glycyrrhizinate in a rat model of ulcerative colitis. World J Gastroenterol. 2006;12(28):4578-81.

72. Misra SM. Integrative Therapies and pediatric inflammatory bowel disease: The current evidence. Children (Basel). 2014;1(2):149-65.

73. Vennat B, Bos MA, Pourrat A, Bastide P. Procyanidins from tormentil: Fractionation and study of the anti-radical activity towards superoxide anion. Biol Pharm Bull. 1994;17(12):1613-5

74. Ben-Arye E, Goldin E, Wengrower D, Stamper A, Kohn $\mathrm{R}$, Berry $\mathrm{E}$. Wheat grass juice in the treatment of active distal ulcerative colitis: A randomized double-blind placebocontrolled trial. Scand J Gastroenterol. 2002;37(4):444-9.

75. Dou H, Chang Y, Zhang L. Coriolus versicolor polysaccharopeptide as an immunotherapeutic in China. Prog Mol Biol Transl Sci. 2019;163:361-81.

76. Mishra SK, Kang JH, Kim DK, Oh SH, Kim MK. Orally administered aqueous extract of Inonotus obliquus ameliorates acute inflammation in dextran sulfate sodium (DSS)-induced colitis in mice. J Ethnopharmacol. 2012; 143(2):524-32

77. Jin Q, Lee C, Lee JW, Lee IS, et al. Chemical constituents from the fruit of Prunus mume. Natural Product Science. 2012;18(3):200-3.

78. Butt MS, Sultan MT. Ginger and its health claims: Molecular aspects. Crit Rev Food Sci Nutr. 2011;51(5): 383-93.

79. dos Reis SB, de Oliveira CC, Acedo SC, et al. Attenuation of colitis injury in rats using Garcinia cambogia extract. Phytother Res. 2009;23(3):324-9.

80. Kar S, Saloni S, Sindhu. Green tea - its chemical constituents and health benefits. IJERT. 2016; 5(2):565-9.

81. Yamada K, Hung P, Park TK, Park PJ, Lim BO. A comparison of the immunostimulatory effects of the medicinal herbs Echinacea, Ashwagandha and Brahmi. J Ethnopharmacol. 2011;137(1):231-5

82. Lin J, Cai QY, Xu W, Lin JM, Peng J. Chemical Composition, Anticancer, Anti-neuroinflammatory, and
Antioxidant Activities of the Essential Oil of Patrinia scabiosae folia. Chin J Integr Med. 2018;24(3):207-12.

83. Jurenka JS. Anti-inflammatory properties of curcumin, a major constituent of Curcuma longa: A review of preclinical and clinical research. Altern Med Rev. 2009; 14(2):141-53.

84. Farzaei MH, Ghasemi-Niri SF, Abdolghafari AH, et al. Biochemical and histopathological evidence on the beneficial effects of Tragopogon graminifolius in TNBSinduced colitis. Pharm Biol. 2015;53(3):429-36.

85. Fakhraei N, Abdolghaffari AH, Delfan B, et al. Protective effect of hydroalcoholic olive leaf extract on experimental model of colitis in rat: Involvement of nitrergic and opioidergic systems. Phytother Res. 2014; 28(9):1367-73

86. Marchi P, Paiotti AP, Artigiani Neto R, Oshima CT, Ribeiro DA. Concentrated grape juice $\left(\mathrm{G} 8000^{\mathrm{TM}}\right)$ reduces immunoexpression of iNOS, TNF-alpha, COX-2 and DNA damage on 2,4,6-trinitrobenzene sulfonic acid-inducedcolitis. Environ Toxicol Pharmacol. 2014;37(2):819-27.

87. Rosillo MA, Sanchez-Hidalgo M, Cárdeno A, de la Lastra CA. Protective effect of ellagic acid, a natural polyphenolic compound, in a murine model of Crohn's disease. Biochem Pharmacol. 2011;82(7):737-45.

88. Guo M, Ding S, Zhao C, et al. Red Ginseng and Semen Coicis can improve the structure of gut microbiota and relieve the symptoms of ulcerative colitis. J Ethnopharmacol. 2015;162:7-13.

89. Okabe N, Yao T. Immunological studies on Crohn's disease. X. Conclusion: A new tentative hypothesis. Med Hypotheses. 1994;43(4):214-8.

90. Shi HY, Ng SC. The state of the art on treatment of Crohn's disease. J Gastroenterol. 2018;53(9):989-98.

91. Hvas CL, Bendix M, Dige A, Dahlerup JF, Agnholt J. Current, experimental, and future treatments in inflammatory bowel disease: A clinical review. Immunopharmacol Immunotoxicol. 2018;40(6):446-60.

92. Guan Q. A comprehensive review and update on the pathogenesis of inflammatory bowel disease. J Immunol Res. 2019;7247238. 